\title{
The microRNA feedback regulation of p63 in cancer progression
}

\author{
Changwei Lin ${ }^{1}$, Xiaorong Li $^{1}$, Yi Zhang ${ }^{2}$, Yihang Guo ${ }^{1}$, Jianyu Zhou ${ }^{1}$, Kai Gao ${ }^{1}$, \\ Jing Dai ${ }^{1}$, Gui Hu${ }^{1}$, Lv Lv ${ }^{1}$, Juan Du ${ }^{1}$, Yi Zhang ${ }^{1}$ \\ 1Department of General Surgery, The Third XiangYa Hospital of Central South University, Changsha, Hunan 410013, P.R. \\ China \\ ${ }^{2}$ Department of General Surgery, The XiangYa Hospital of Central South University, Changsha, Hunan 410013, P.R. China \\ Correspondence to: \\ Xiaorong Li, e-mail: lixiaorong@medmail.com.cn
}

Keywords: p63, microRNA, cancer, feedback

Received: September 23, $2014 \quad$ Accepted: December 31, $2014 \quad$ Published: January 23, 2015

\section{ABSTRACT}

The transcription factor p63 is a member of the p53 gene family that plays a complex role in cancer due to its involvement in epithelial differentiation, cell cycle arrest and apoptosis. MicroRNAs are a class of small, non-coding RNAs with an important regulatory role in various cellular processes, as well as in the development and progression of cancer. A number of microRNAs have been shown to function as transcriptional targets of p63. Conversely, microRNAs also can modulate the expression and activity of p63. However, the p63-microRNA regulatory circuit has not been addressed in depth so far. Here, computational genomic analysis was performed using miRtarBase, Targetscan, microRNA.ORG, DIANA-MICROT, RNA22-HSA and miRDB to analyze miRNA binding to the 3'UTR of p63. JASPAR (profile score threshold $80 \%$ ) and TFSEARCH datasets were used to search transcriptional start sites for p53/ p63 response elements. Remarkably, these data revealed 63 microRNAs that targeted p63. Furthermore, there were 39 microRNAs targeting p63 that were predicted to be regulated by p63. These analyses suggest a crosstalk between p63 and microRNAs. Here, we discuss the crosstalk between p63 and the microRNA network, and the role of their interactions in cancer.

\section{INTRODUCTION}

The regulation of gene expression is implicated in multiple molecular mechanisms, which include transcriptional, translational, and post-translational regulatory mechanisms $[1,2]$. In addition, the modulation of gene expression by transcription factors and microRNAs (miRNAs) is implicated in the control of gene expression [3-5].

P63 is a member of the p53 gene family of transcription factors $[6,7]$. Like other members of the p53 family [8], the p63 gene generates multiple protein isoforms with distinct properties from two distinct promoters [9]. The transcription of promoter 1, located upstream of exon 1 , results in the expression of p63 transcripts containing the N-terminal transactivation domain (TA isoform). Alternatively, transcription from promoter 2, located in an intron, generates p63 transcripts with an $\mathrm{N}$-terminal truncated isoform ( $\triangle \mathrm{N}$ isoform) (Figure 1A) [10]. Moreover, both TAp63 and $\Delta \mathrm{Np} 63$ can be alternatively spliced at the
C-terminal sequence to generate three isoforms named $\alpha$, $\beta$ and $\gamma$ (Figure 1B) [11]. TAp63 is related to cell-cycle arrest and apoptosis and, similar to p53 [12], low levels of TAp63 are detected in various types of cancer tissues $[13,14]$. Conversely, $\Delta \mathrm{Np} 63$ has been implicated in cell proliferation and cell adhesion $[15,16]$, and this isoform is usually overexpressed in tumor tissues [17-19]. Thus, p63 exhibits isoform-specific expression and functions in human cancer [20,21].

Although p63 has been shown to closely associate with cancer development, the underlying molecular mechanisms have not been fully elucidated. In fact, many studies indicate that transcriptional regulation of p63 is one of the most important mechanisms in various tumor processes by triggering the expression of oncogenes $[22,23]$. TAp63 is a proven transcription factor that activates downstream targets with an N-terminal transactivation (TA) domain. $\triangle \mathrm{Np} 63$ was originally believed to be a dominant negative transcriptional repressor because it lacks the $\mathrm{N}$-terminal TA domain. 

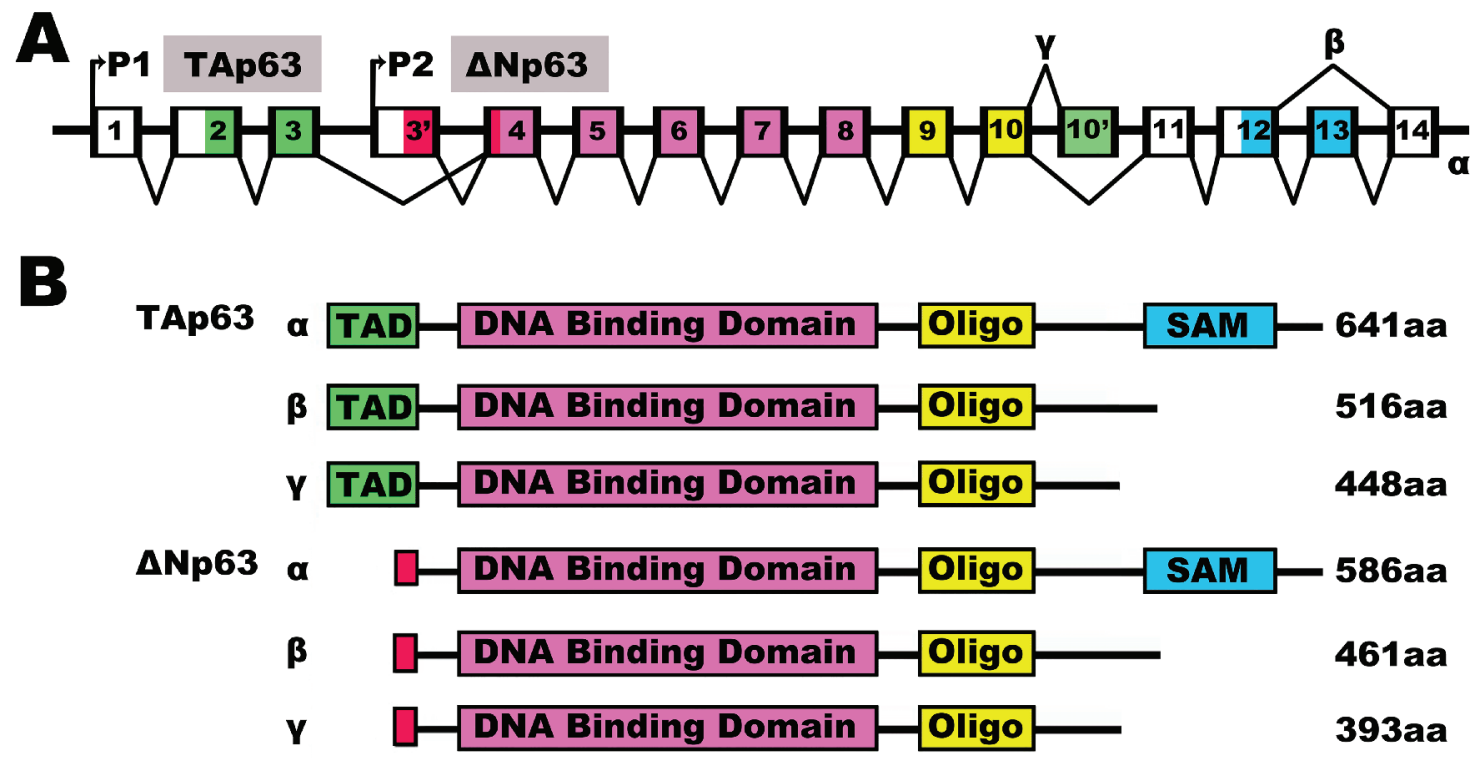

Figure 1: The human p63 splicing isoforms. The human p63 splicing isoforms. (A) Schematic representation of intron/exon structure of the human p63 gene. The $\mathrm{p} 63$ gene has two promoters with the P1 promoter coding for TA (transactivation) isoforms and the P2 promoter coding for $\mathrm{N}$-terminally truncated $(\Delta \mathrm{N})$ isoforms. Introns are depicted in white, while exons are colored according to the functional domains (see B). P63 genes express three splice variants and contain different internal promoters. (B) Schematic representation of the human p63 protein splicing variants. Various human p63 variants encoded by the p63 gene with indicated amino acid identity above the TA, DNA binding and oligomerization domain. TAD, Transactivation domain; $\Delta \mathrm{N}$, N-terminally truncated variants; Oligo, Oligomerization domain; SAM, Sterile alpha motif.

However, it has been reported that $\Delta \mathrm{Np} 63$ indeed has transcriptional activity due to the presence of alternative transactivation domains [24, 25]. Furthermore, an increasing number of studies have revealed that p63 activation is able to modulate the expression of miRNAs, which in turn can dampen the expression of hundreds of genes. Indeed, TAp63 may be able to inhibit metastasis by directly activating DICER and miR-130b [26], and $\Delta \mathrm{Np} 63$ may enhance cell migration and metastasis by directly activating miR-205 [27].

miRNAs are 18- to 24-nucleotide non-coding RNA molecules [28]. It regulates gene expression at the post-transcriptional level by targeting to sites in the 3' untranslated region (UTR) of messenger RNA (mRNA) and leading to mRNA degradation or inhibition of translation. It has been reported that miRNAs may regulate over $60 \%$ of mRNAs $[29,30]$. miRNAs have been implicated in cellular differentiation, development, proliferation and apoptosis [31]. However, in cancer, imbalances in miRNA expression lead to the malfunction of these processes [32-34]. Thereby, miRNAs are likely to play their decisive role in tumor progression, diagnosis and prognosis [35-37].

miRNAs are canonically produced through a multistep process and transcription factors are recognized as key regulatory points for miRNA production [38]. Abnormal expression of transcription factors, such as $\mathrm{p} 63$, can promote miRNA imbalance and tumor progression $[39,40]$. In fact, miRNAs can be transcriptionally or nontranscriptionally regulated by p63 [41]. Alternatively, the transcription factor activity of p63 has been shown to function downstream of miRNAs. miRNAs can regulate p63 by direct suppression of $\mathrm{p} 63$ expression or alternative indirect mechanisms [42]. These findings suggest that miRNAs are important components of the p63 network. Here, we provide an overview of the potential roles of the crosstalk between $\mathrm{p} 63$ and miRNAs in tumor suppression and cancer prevention.

\section{Alteration of p63 expression in human cancer}

The human $\mathrm{p} 63$ gene belongs to the $\mathrm{p} 53$ family and plays a crucial role in maintaining genomic stability and suppressing tumor formation [43]. Although it has been suggested that p63 is involved in tumorigenesis, its role in either cancer initiation or progression is controversial [44]. Initially, several thorough analyses of p63 expression in cancer tissues demonstrated that $\mathrm{p} 63$ was often upregulated at the transcriptional level in squamous cell carcinoma $[45,46]$. This strong evidence supported an oncogenic role for p63 in tumorigenesis despite its homology with $\mathrm{p} 53$, which is a classic tumor suppressor that originally suggested a tumor suppressive role for p63 [47]. These apparently contradictory results were surprising.

The p63 gene contains two promoters and produces two diametrically opposite groups of isoforms: those containing the transactivation (TA) domain (TAp63), and those lacking it ( $\triangle \mathrm{Np} 63)[48] . \Delta \mathrm{Np} 63$ is transcribed from the second transcriptional start site within the p63 gene 
with three different $\mathrm{C}$-termini termed $\alpha, \beta$ and $\gamma$, and it only contains a DNA binding domain and an oligomerization (oligo) domain. Because $\Delta \mathrm{Np} 63$ isoforms lack the $\mathrm{N}$-terminal TA domain, they were originally believed to be dominant negative transcriptional repressors. However, it has become clear that they also have transcriptional activity attributed to other transactivation domains [49]. $\Delta \mathrm{Np} 63$ has also been implicated in cell proliferation and cell adhesion $[50,51]$. Crook $\mathrm{T}$ et al. showed that $\Delta \mathrm{Np} 63$ was overexpressed in 25 primary nasopharyngeal carcinomas [52]. Various studies have proven that $\Delta \mathrm{Np} 63$ is an oncogene [53, 54]. Interestingly, Cui R's study suggested that both TAp63 and $\triangle \mathrm{Np} 63$ isoforms are specifically upregulated at the transcriptional level in squamous cell carcinoma, and $\Delta \mathrm{Np} 63$ was the predominant isoform expressed at the protein level [55]. These findings prompted us to investigate the roles of TAp63 in cancer.

TAp63 is transcribed from the first transcriptional start site within the p63 gene and contains the transactivation domain and three different C-termini termed $\alpha, \beta$ and $\gamma$ [56]. The highlighted regions of TAp63 are the transactivation (TA) domain, DNA binding domain and oligomerization (oligo) domain [57]. TAp63 $\alpha$ and $\Delta \mathrm{Np} 63 \alpha$ proteins contain an additional region referred to as the sterile alpha motif, or SAM domain, that is not found in p53 [58]. The SAM domain is a protein-protein interaction domain that was initially implicated in developmental processes and is involved in other processes such as apoptosis, transcription, and adhesion [59]. The most significant difference between TAp63 and $\Delta \mathrm{Np} 63$ is in the transactivation (TA) domain [60]. Similar to p53, TAp63 expression can be induced in response to cellular stress. It is also part of the DNA damage response function, which induces cell-cycle arrest and apoptosis $[61,62]$. Therefore, TAp63 is usually detected at low levels in cancer tissue $[63,64]$. Accumulated studies suggested that TAp63 exerts different effects in carcinogenesis [65-67].

The role of p63 in tumorigenesis is very complex. Thus, more work is needed to explain how the differential expression of the p63 isoforms could influence this process. Considering the fact that all p63 isoforms contain a DNA binding domain and are able to bind to thousands of gene promoters, studying their interaction with regulatory genes may not only increase our understanding of the role of p63 in tumorigenesis, but could also open the door to the development of innovative diagnostic procedures and targeted therapies.

\section{miRNAs and their role in tumorigenesis}

miRNAs are small, non coding RNAs with a length of 18 to 24 nucleotides [68]. They play an important role in all biological processes by post-transcriptionally regulating gene expression [69]. To date, approximately 1,881 precursors and 2,588 mature miRNAs have been identified in humans (Homo sapiens, miRbase release
21) $[70,71]$. Computational and experimental approaches indicate that a single miRNA may repress more than one hundred mRNAs by annealing to the 3'UTR of gene transcripts [72]. Therefore, miRNAs are considered to regulate approximately $60 \%$ of human protein-coding genes [73], and constitute one of the most abundant classes of gene-regulatory molecules in animals by leading to mRNA degradation or the inhibition of translation [74]. It is noteworthy that recent evidence suggests that miRNAs exert a uniquely important role in cellular differentiation, development, proliferation and apoptosis [75, 76]. Thus, it is not surprising that dysfunction of miRNAs in malignancies is involved in cancer pathogenesis $[77,78]$, chemo/radiotherapy resistance $[79,80]$, tumor metastasis $[81,82]$, and other tumor-promoting mechanisms.

miRNAs are encoded throughout the human genome. Most miRNAs are found within intragenic regions as well as protein-coding or non-coding transcriptional units [83]. The production of miRNAs is a multistep process that is composed of three main events: cropping, export and dicing [84-87]. First, a miRNA gene is transcribed as primary capped and polyadenylated precursors of miRNA (pri-miRNA) by transcription factors and RNA polymerase II [88]. Then, these several kilobaselong transcripts are cleaved by the nuclear Drosha/DGCR8 heterodimer that releases a hairpin-structured pre-miRNA of 60-100 nucleotides [89]. Finally, Pre-miRNAs are cleaved into an 18-24 nucleotide mature miRNA duplex by the RNAseIII Dicer $[90,91]$. One strand of the duplex (the guide strand of the miRNA) is then incorporated into the RNA-induced silencing complex (RISC) before annealing to its mRNA targets, whereas the other strand (the passenger strand) is degraded [92, 93].

As discussed previously, miRNA biogenesis is a complex multistep process, and each step of this process is tightly regulated. Mutation or aberrant expression of any component of the miRNA biogenesis machinery could contribute to a dysregulation in miRNA expression in tumors. The majority of miRNAs are transcribed by RNA polymerase II and III, and transcription factors significantly contribute to the activation of their expression by directly binding to the promoters of miRNAs. Recent evidence indicates that p63mediated activation of miRNA transcription is an important event in the regulation of miRNA levels $[94,95]$.

\section{Transcriptional regulation of miRNAs by p63}

Dysregulation of miRNA expression is common in human cancers. However, the mechanisms underlying miRNA dysregulation are not clear. As described above, transcriptional regulation is one of the most important steps in the synthesis of miRNAs. Transcriptional activation and repression of specific microRNAs by $\Delta \mathrm{Np} 63 \alpha$ was shown to attenuate the expression of several proteins involved in cell death and survival and to regulate tumor cell resistance to cisplatin [96]. In human bladder 
cancer cells, stable knockdown of $\Delta \mathrm{Np} 63 \alpha$ decreased binding of RNA Pol II to the miR-205 "host" gene (miR-205HG) promoter and reduced the expression of the primary and mature forms of miR-205 [97]. Finally, $\Delta \mathrm{Np} 63 \alpha$ decreased the levels of miR-205. Members of the miR-200 family are known regulators of cancer stem cells and epithelial-mesenchymal transitions. Knouf EC et al. found that p63 modulates the promoter activity of miRNAs of the miR-200 family by directly associating with the miR-200b/a/429 promoter, and p63 binding sites were significantly overrepresented among miRNA genes that were overexpressed in ovarian carcinoma [98]. In addition, p63 also proved to be an important regulator of apoptosis, proliferation, invasion, and metastasis in cancer cells by directly regulating the transcription of the miR-34 family [99], miR-138 and miR-181 [100].

Another important transcriptional program that has been identified involves post-transcriptional control of miRNAs by p63. The cropping step regulated by the Drosha/DGCR8 heterodimer is an important event in regulation of miRNA levels. There has been no direct study to prove that p63 can directly regulate the expression of Drosha. However, it has been reported that PY domaincontaining proteins interact with WW domain-containing proteins. Interestingly, p63 contains a PY domain [101], while DGCR8 contains a WW domain [86], supporting the possibility of an interaction between p63 and DGCR8. Additionally, a study by Chakravarti D et al. showed that $\triangle \mathrm{Np} 63$ is a transcriptional activator of DGCR8 [94]. Accumulating evidence has indicated that p63 can influence the ability of DGCR8 to process pre-miRNAs by regulating its expression [102]. As previously discussed, pre-miRNAs are cleaved in the cytoplasm near the terminal loop, a process that requires the RNAseIII Dicer. Several mechanisms can regulate Dicer expression, including the transcription factor p63. There are several TAp63 binding sites that have been identified within the Dicer promoter. Therefore, TAp63 can drive the expression of Dicer to influence the maturation of miRNAs (miR-31, miR-203, miR-130b, and miR-206) [103]. Huang Y et al's study suggests a synergistic effect of the Dicer-dependent miRNA (miR-630 and miR-885-3p) maturation after $\mathrm{p}-\Delta \mathrm{Np} 63 \alpha$-dependent miRNA transcriptional activation [104]. Interestingly, Boominathan L performed a study that investigated the relationship between p63 and the miRNA processing complex, and discovered that p63 was an important part of this complex during the maturation of miRNAs [105]. Furthermore, Boominathan L analyzed the promoter sequence of Drosha, DGCR8, Dicer and TARBP2 for p63 response elements (REs) and found several p63 and p53 REs in the promoter of a number of miRNA-processing components. He proposed a number of tumor suppressor pathways to illustrate p63 could function as both positive and negative regulators of miRNA through direct or indirect mechanisms [41]. Although the proposed pathways were not confirmed or validated by experimental studies, they provide a systemic overview of the interaction of the p53 family with miRNAs. Moreover, these two articles provide a new direction and methods for studying the interaction between p53 family and miRNAs, especially in the prediction of p53-REs and miRNA targets.

Furthermore, p63 can control the expression of miRNAs by regulating the expression of miRNA transcription factors, as well as several key regulatory factors that allow for the correct maturation of primary miRNA. As an example of the former, the gene of the transcription factor early growth response 2 (EGR2) contains a p63 RE and is therefore a direct target of p63 [106]. Interestingly, it has recently been shown that EGR2 can bind to the pre-miR-142-3p promoter to regulate its expression [107]. Thus, it is plausible that p63 could regulate the expression of miR-142-3p through EGR2. Runt-related transcription factor 1 (RUNX1) has been identified as a direct target of p63 transcriptional regulation [108], and this transcription factor can regulate miR-424 expression [109]. Altogether, these findings suggest that p63 can promote the expression of $\mathrm{miR}-142-3 \mathrm{p}$ by regulating the transcription of RUNX1. Recently, the Drosha gene promoter has been shown to be a target of the NFkB transcription factor [110]. Another study showed that TAp63 can regulate NF- $\kappa B$ transcription and protein stability [111]. These data suggest that $\mathrm{p} 63$, by regulating the transcription of $\mathrm{NF}-\kappa \mathrm{B}$, can promote the association between Drosha and pri-miRNAs. Moreover, it is reported that $\mathrm{p}-\Delta \mathrm{Np} 63 \mathrm{a}$ is necessary to induce gene promoters for microRNAs (630 and 885-3p), together with certain transcriptional coactivators (e.g., CARM1, KAT2B, TFAP2A). Additionally, p- $\triangle N p 63 a$, together with transcriptional corepressors (e.g., EZH2, CTBP1, HDACs), is needed to repress promoters for microRNAs (181a-5p, 374a-5p and 519a-3p) in SCC cells exposed to cisplatin [96]. These data suggest that $\mathrm{p} 63$, by regulating the transcription of miRNAs, plays important roles in various cancers (Figure 2). The miRNAs demonstrated to be regulated by p63 are summarized in Table 1.

\section{Regulation of p63 by miRNAs}

As discussed above, p63 has been defined as a regulator of miRNAs. Conversely, p63 expression can also be controlled by specific miRNAs in certain tissues. Recent studies identified p63 as one of the conserved targets of miR-203 [112-114], and regulation of the expression of $\Delta \mathrm{Np} 63$ is an important molecular step for miR-203-induced suppression of proliferation and cellcycle arrest [115-117]. Lena AM et al. confirmed these findings and noted that miR-203 can regulate $\Delta \mathrm{Np} 63$ levels in head and neck squamous cell carcinoma [118] and significantly suppress the proliferation and migration of these cancer cells [119-120]. In addition, a study by Manni I et al. demonstrated that p63 is a direct target of miR-92, and concluded that negative regulation of $\Delta \mathrm{Np} 63$ expression is one of the molecular mechanisms through which miR-92 inhibits cell proliferation [123].

Additionally, Papagiannakopoulos T et al. showed for the first time that miR-21 targets the tumor-suppressive 


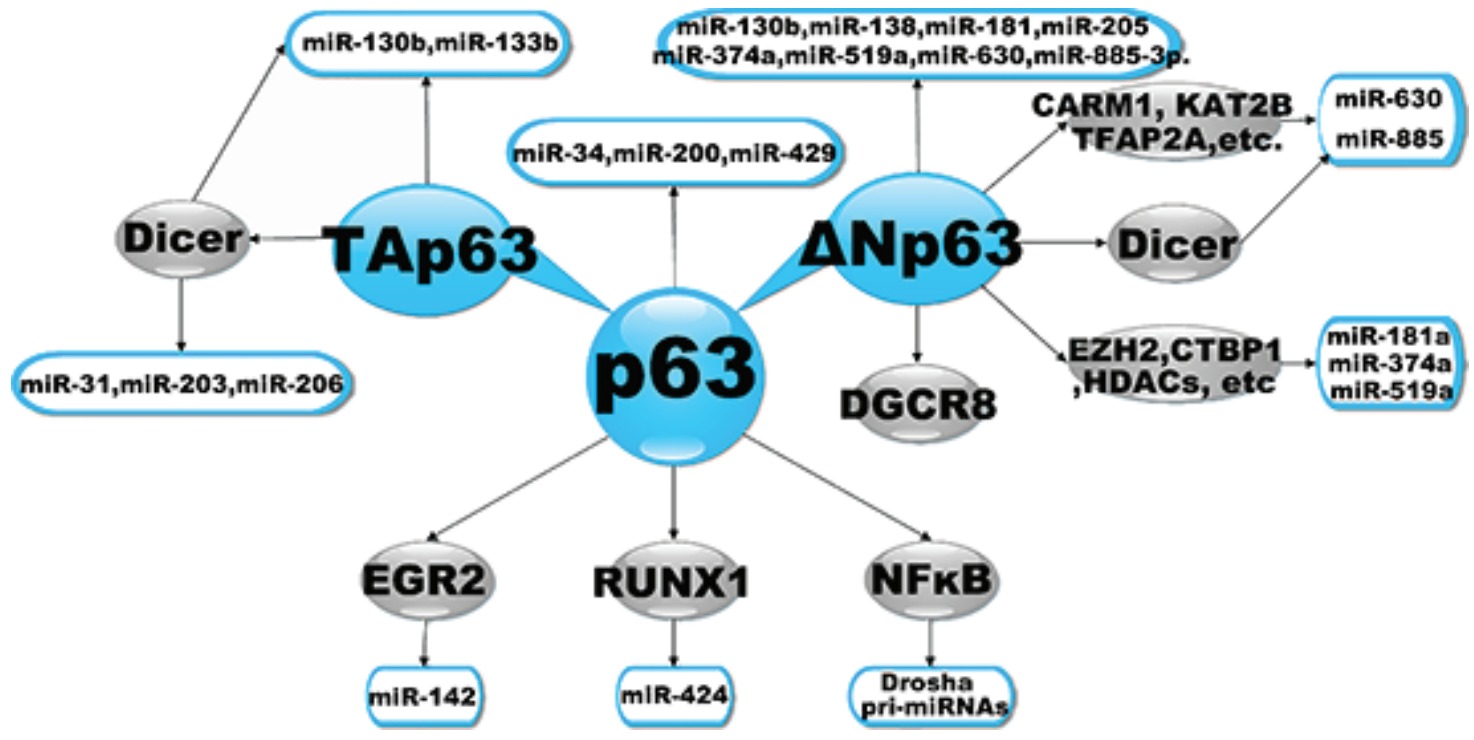

Figure 2: Transcriptional Regulation of miRNAs by p63. The diagram illustrates a simple schematic to highlight points of transcriptional regulation of miRNAs by p63. It illustrates that the p63 could modulate the expression of miRNAs by directly or alternative indirectly mechanisms.

Table 1: The miRNAs demonstrated to be transcriptional regulated by p63

\begin{tabular}{|c|c|}
\hline \multicolumn{1}{|c|}{ miRNA Name } & {$[128]$} \\
\hline let7-5p & {$[136]$} \\
\hline Let7i & {$[26,100]$} \\
\hline miR-130b & {$[131]$} \\
\hline miR-133b & {$[100]$} \\
\hline miR-138 & {$[63]$} \\
\hline miR-155 & {$[96,100,104,130]$} \\
\hline miR-181 & {$[128]$} \\
\hline miR-185-5p & {$[138]$} \\
\hline miR-193a-5p & {$[98]$} \\
\hline miR-200 & {$[27,97]$} \\
\hline miR-205 & {$[96]$} \\
\hline miR-297 & {$[99]$} \\
\hline miR-34 & {$[104,130]$} \\
\hline miR-374a & {$[98]$} \\
\hline miR-429 & {$[96]$} \\
\hline miR-485-5p & {$[104,130]$} \\
\hline miR-519a & {$[104,130]$} \\
\hline miR-630 & {$[104,130]$} \\
\hline miR-885-3p & {$[96]$} \\
\hline miR-92b-3p & \\
\hline
\end{tabular}


protein TAp63, and confirmed that miR-21 is necessary for suppression of apoptosis in glioblastoma cells [121]. Wang $\mathrm{T}$ et al. found that TAp63 was a target of miR21 in $\mathrm{HaCaT}$ cells, and this miRNA could regulate the response of epithelial cells to TGF- $\beta$ with a potential impact on tumorigenesis [122]. Furthermore, researchers demonstrated that both miR-21 and miR-30b/c can target the 3'UTR of TAp63 mRNA and that TAp63 proteins mediate some of the effects of miR-21 and miR-30 on tumor necrosis factor-related apoptosis-inducing ligand (TRAIL) resistance in primary human glioblastoma cells and lung cancer cells [124]. Endogenous miR302 was also proven to reduce p63 protein and mRNA levels through two target sites within the p63 3'UTR in testicular cancer cells, indicating that miR-302 may counteract apoptosis [125]. The miRNAs that have been demonstrated to regulate p63 are listed in Table 2.

Given these findings, p63 isoforms regulated by miRNAs can be divided into two classes: $\Delta$ Np 63 -isoforms, which enhance cell proliferation and repress apoptosis and are repressed by miR-92 and miR-203, and Tap63isoforms, which induce cell cycle arrest and apoptosis and are repressed by miR-21, miR-30 and miR-302 (Figure 3).

As shown by the above examples, an emerging consensus is that the transcription factor p63 is particularly prominent within regulatory circuits controlling the expression and function of miRNAs. It has been reported that $\triangle \mathrm{Np} 63$ can inhibit miR-130b expression by binding directly to p63-Res located in close proximity to the genomic locus of miR-130b. Conversely, $\Delta \mathrm{Np} 63$ expression can also be inhibited by miR-130b [100]. Thus, it is plausible that p63 and miR-130b are able to regulate one another to form a p63/ miR-130b autoregulatory feedback loop [100]. In addition, p63 and miR-92 have been shown to form a p63/miRNA autoregulatory feedback loop [96, 123]. Phosphorylation is a prevalent mechanism by which the activity of transcription factors is regulated rapidly in response to changes in the cellular environment, and it provides dynamic and precise tuning of their transactivation potential. Accumulated evidence suggests that the phosphorylated- $\Delta$ Np63 $\alpha$ (p- $\Delta \mathrm{Np} 63 \alpha$ ) transcription factor is indispensable for activation and inhibition of the expression of specific genes $[126,127]$. As the expression of miRNAs is consistently maintained by RNA polymerase II and III transcriptional machinery, the regulatory role of $\mathrm{p}-\Delta \mathrm{Np} 63 \alpha$ in the miRNA maturation process is highly evident $[128,129]$. Indeed, Huang $\mathrm{Y}$ et al. demonstrated that $\mathrm{p}-\Delta \mathrm{Np} 63 \alpha$ can transcriptionally regulate microRNA gene promoters, while total $\Delta \mathrm{Np} 63 \alpha$ levels and $\mathrm{p}-\Delta \mathrm{Np} 63 \alpha$ levels are maintained by miRNAs [130]. P- $\Delta$ Np63 $\alpha /$ microRNA feedback regulation plays a key role in squamous carcinoma cells exposed to cisplatin, thereby revealing a regulatory feedback loop between p63 and miRNAs (Figure 3) [96]. These results prompted us to analyze miRNA binding to the 3'UTR of p63 via multiple components, including miRtarBase, Targetscan, microRNA.ORG, DIANA-MICROT, RNA22-HSA and miRDB. Table 3 refers to miRNAs that are predicted to target p63 mRNA by at least two different algorithms. Because p63 can bind to p53 consensus sequences [99], we screened a region of $\sim 2000$ bp upstream of the miRNAs listed in Table 3 and searched transcriptional start sites for $\mathrm{p} 53 / \mathrm{p} 63$ Res using the JASPAR (profile score threshold 80\%) and TFSEARCH datasets. Remarkably, bioinformatic analyses revealed many p53- and p63-Res in the promoters of miRNAs, indicating that they could be direct transcriptional targets of p63 (Table 4). In support of this data, we screened a region of $\sim 2000 \mathrm{bp}$ upstream of the miR-133b transcriptional start site for p53RE. We showed that Tap63 could directly transcriptionally regulate miR-133b [131]. Collectively, these findings suggest a feed-forward loop, where p63 expression

Table 2: The miRNAs demonstrated to regulate p63

\begin{tabular}{|c|c|}
\hline \multicolumn{1}{|c|}{ miRNA name } & References \\
\hline miR-130b & {$[100]$} \\
\hline miR-181a & {$[130]$} \\
\hline miR-196a2* & {$[137]$} \\
\hline miR-203 & {$[112-120]$} \\
\hline miR-21 & {$[121,122]$} \\
\hline miR-30b/c & {$[124]$} \\
\hline miR-302 & {$[125]$} \\
\hline miR-374a & {$[130]$} \\
\hline miR-519a & {$[130]$} \\
\hline miR-630 & {$[130]$} \\
\hline miR-885-3p & {$[130]$} \\
\hline miR-92 & {$[123]$} \\
\hline
\end{tabular}




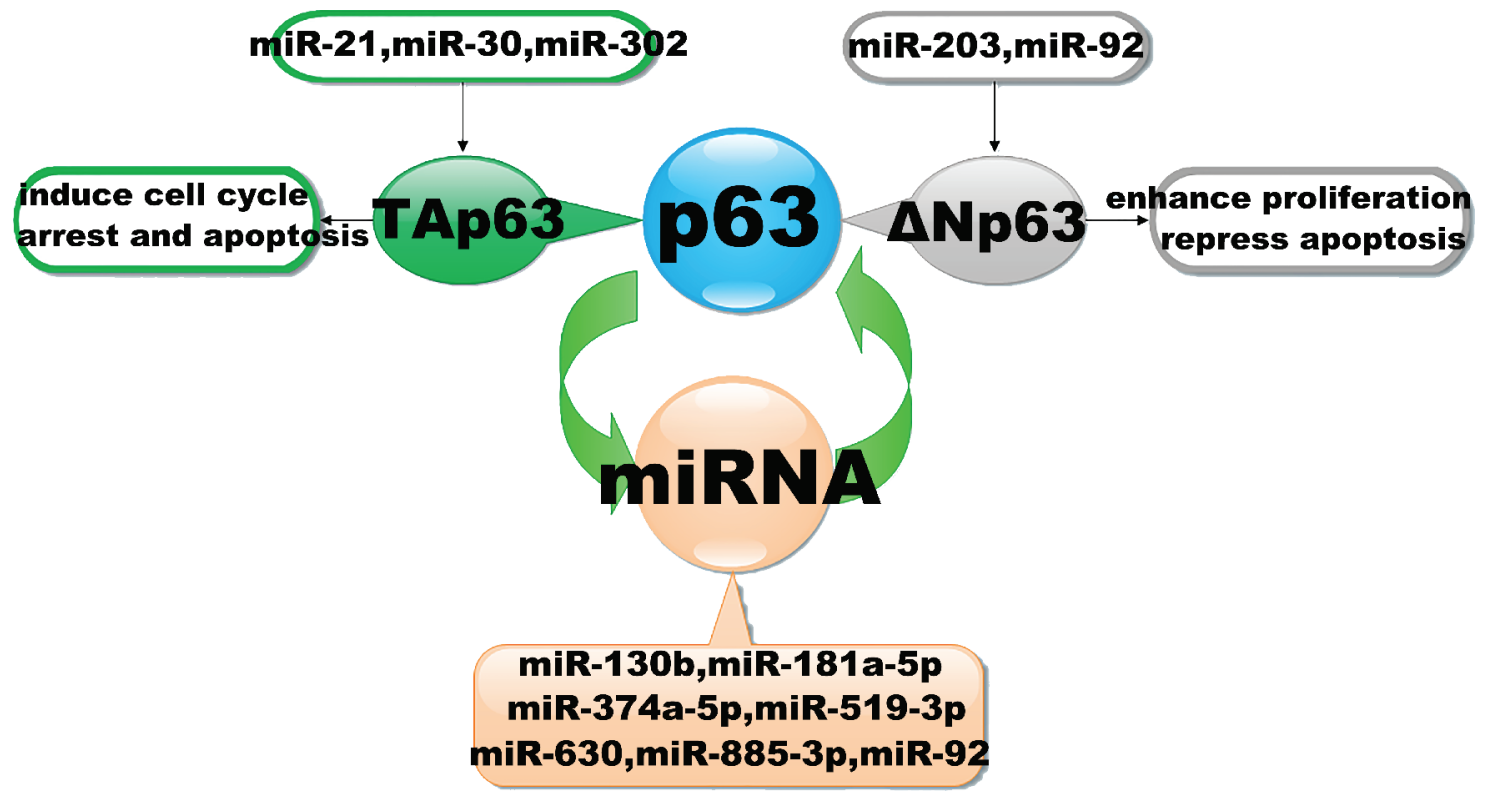

Figure 3: Interaction of miRNAs with the p63 signalling pathway. The diagram schematic represented the regulatory loops that exist between p63 and miRNAs. It illustrates that miRNAs could regulate the expression by targeting to p63. Conversely, miRNAs expression also could be inhibited by p63.

suppresses miRNAs, as well as a negative feedback loop, where p63 expression regulates via its own 3'UTR and miRNAs. Taken together, the molecular interrelationship between p63 and specific miRNAs is a key functional network in tumorigenesis. Although we are only beginning to uncover their complexity, such circuits will occupy a particularly important role within the relationship between p63 and miRNAs.

\section{Conclusion and future perspective}

It is well established that p63 plays an important role in the development and progression of cancer. Accordingly, p63 functions within a wide biological spectrum, stretching from epidermal mesenchymal transition [132] to senescence, cell death and cell cycle arrest [133]. These states are all determinants in cancer progression, and thus p63 affects the chemosensitivity of tumors [134]. In addition, p63 is deregulated in tumor tissues, and there has been much debate as to whether p63 behaves as a tumor suppressor gene or an oncogene, as current studies support both sides. The P63 gene encodes two major protein isoforms, TAp63 and $\Delta \mathrm{Np} 63$, which have opposing regulatory functions on downstream target genes $[135,136]$. Previous studies have shown that $\mathrm{p} 63$, by regulating the transcription of miRNAs, contributes to multiple mechanisms implicated in the development and progression of cancer. The diverse actions of these miRNAs affected by TAp63 isoforms and $\Delta$ Np63 isoforms further complicate the tumor cell response. The former generally act as pro-apoptotic and tumor suppressive agents, while the latter function more as an anti-apoptotic and oncogenic factors.
miRNAs are small, non-coding RNAs that typically inhibit the translation and stability of mRNAs. Over $60 \%$ of human protein-coding genes are predicted to be controlled by miRNAs. It is clear that miRNAs provide a complicated regulation of the signaling networks involved in cellular processes such as differentiation, stress response, cell cycle regulation, apoptosis, and migration. Thus, miRNA dysregulation has been shown to play an essential role in the development and progression of cancer. Furthermore, miRNAs are able to target the p63 gene, a key regulator of the surveillance network, potentially providing a new means of perturbing p63 signaling networks in cancer. The components of the miRNA network consist of hundreds of protein-coding genes, including those acting upstream to regulate miRNA expression, those functioning downstream to mediate miRNA effects, and those forming regulatory feedback loops.

Our review covers the p63/miRNA autoregulatory feedback loop. There are, in total, approximately 39 pairs of p63-miRNA feedback predicted. Four of these $(\Delta \mathrm{Np} 63 / \mathrm{miR}-130 \mathrm{~b}, \Delta \mathrm{Np} 63 / \mathrm{miR}-92, \Delta \mathrm{Np} 63 / \mathrm{miR}-181 \mathrm{a}-5 \mathrm{p}$ and $\Delta$ Np63/miR-374a-5p) have been validated $[96,100$, $123,130]$. A study by Huang et al. revealed and validated three additional p63-miRNA feedback loops $(\Delta \mathrm{Np} 63 /$ miR-519a-3p, $\Delta$ Np63/miR-630 and $\Delta$ Np63/miR-885$3 p)$. Interestingly, we were unable to find the p53/p63Res showing that 63 binds to the promoter of these three miRNAs (miR-519a-3p, miR-630 and miR-885-3p) in the JASPAR (profile score threshold 80\%) datasets. Although very little is currently known about the p63/miRNA autoregulatory feedback loop, it is likely that it plays an important role in tumorigenesis. Moreover, the expression of p63 and miRNAs, as well as the isoforms of p63 that are 
Table 3: Identified miRNAs targeting the 3'UTR of p63 mRNA by web algorithms

\begin{tabular}{|c|c|c|}
\hline miRNA & Sequence & algorithms \\
\hline hsa-miR-1297 & $\begin{array}{l}\text { 3' guggacuuaaUGAACUu 5' hsa-miR-1297 } \\
\qquad|||||| \\
\text { 5' ccagaaccacACUUGAa 3' TP63 }\end{array}$ & microRNA.ORG Targetscan \\
\hline hsa-miR-130a & $\begin{array}{l}\text { 3' uacgggaaAAUUGUAACGUGAc 5' hsa-miR-130a } \\
\qquad|||||| \mid \\
\text { 5' aaagaaaaUUGA--GUUGCACUu 3' TP63 }\end{array}$ & $\begin{array}{c}\text { microRNA.ORG Targetscan } \\
\text { DIANA-MICROT }\end{array}$ \\
\hline hsa-miR-130b & $\begin{array}{l}\text { 3' uacgggaaaguagUAACGUGAc 5' hsa-miR-130b } \\
\qquad|||||| \mid \\
\text { 5' gaaagaaaauugaGUUGCACUu 3' TP63 }\end{array}$ & $\begin{array}{c}\text { microRNA.ORG Targetscan } \\
\text { DIANA-MICROT }\end{array}$ \\
\hline hsa-miR-133b & $\begin{array}{l}\text { 3' aucgaccAACUUCCCCUG--GUUu 5' hsa-miR-133b } \\
\qquad|||||||||| \\
\text { 5' gaaucuuUUGAA--GGGACUCAAa 3' TP63 }\end{array}$ & $\begin{array}{l}\text { microRNA.ORG } \\
\text { RNA22-HSA }\end{array}$ \\
\hline hsa-miR-136 & $\begin{array}{l}\text { 3' agguagUAGUUUUGUUUACCUCa 5' hsa-miR-136 } \\
\qquad|||| \mid \\
\text { 5' cuagaaAGUGGGCUUAAUGGAGu 3' TP63 }\end{array}$ & microRNA.ORG miRDB \\
\hline hsa-miR-140 & $\begin{array}{l}\text { 3' gaUGGUAUCCCAUUUUGGUGAc 5' hsa-miR-140 } \\
\qquad|||||||| \\
\text { 5' cuGCUGU--UGCUUAAACCACUu 3' TP63 }\end{array}$ & $\begin{array}{c}\text { microRNA.ORG DIANA- } \\
\text { MICROT }\end{array}$ \\
\hline hsa-miR-149 & $\begin{array}{l}\text { 3' cccucacuucugugccUCGGUCu 5' hsa-miR-149 } \\
\qquad|||||| \\
\text { 5' uuaaaaggcccauagc AGCCAGu 3' TP63 }\end{array}$ & $\begin{array}{l}\text { microRNA.ORG DIANA- } \\
\text { MICROT }\end{array}$ \\
\hline hsa-miR-181a & $\begin{array}{l}\text { 3' ugaguggcugucgcAACUUACAa 5' hsa-miR-181a } \\
\qquad|||||||| \\
\text { 5'caguaugugggauaUUGAAUGUu 3' TP63 }\end{array}$ & microRNA.ORG miRDB \\
\hline hsa-miR-181b & $\begin{array}{l}\text { 3' uggguggcugucGUUACUUACAa 5' hsa-miR-181b } \\
\qquad|||||||||| \mid \\
\text { 5' caguaugugggaUAUUGAAUGUu 3' TP63 }\end{array}$ & microRNA.ORG miRDB \\
\hline hsa-miR-181c & $\begin{array}{l}\text { 3' ugagugGCUGUCCAACUUACAa 5' hsa-miR-181c } \\
\qquad|||||||| \\
\text { 5' aguaugUGGGAUAUUGAAUGUu 3' TP63 }\end{array}$ & microRNA.ORG miRDB \\
\hline hsa-miR-181d & $\begin{array}{l}\text { 3' uggguggcugUUGUUACUUACAa 5' hsa-miR-181d } \\
\qquad|||||| \mid \\
\text { 5' caguauguggGAUAUUGAAUGUu 3' TP63 }\end{array}$ & microRNA.ORG miRDB \\
\hline hsa-miR-186 & $\begin{array}{l}\text { 3' ucggguUUUCCUCUUAAGAAAc 5' hsa-miR-186 } \\
\qquad|||||||| \\
\text { 5' gacuguAGAUAUGUAUUCUUUu 3' TP63 }\end{array}$ & microRNA.ORG miRDB \\
\hline hsa-miR-203 & $\begin{array}{l}\text { 3' gaUCACCAGGAUU-------UGUAAAGUg 5' hsa-miR-203 } \\
\qquad \text { 5' acAGAGGUAUUAAAACUAAAUUUCAc 3' TP63 }^{\prime} \text { | | | | }\end{array}$ & microRNA.ORG miRtarBase \\
\hline hsa-miR-204 & $\begin{array}{l}\text { 3' uccGUAUCCUACUGUUUCCCUu 5' hsa-miR-204 } \\
\qquad|||||| \mid \\
\text { 5'ggaUAUUGAAUGUUAAAGGGAu 3' TP63 }\end{array}$ & microRNA.ORG miRDB \\
\hline hsa-miR-21 & $\begin{array}{l}\text { 3' aguuGUAGUCA--GACUAUUCGAu 5' hsa-miR-21 } \\
\qquad|||||| \\
\text { 5' gggcUGUCAUUGCACAUAAGCUu 3' TP63 }\end{array}$ & microRNA.ORG miRtarBase \\
\hline
\end{tabular}

(Continued) 


\begin{tabular}{|c|c|c|}
\hline hsa-miR-211 & $\begin{array}{l}\text { 3' uccgcuuCCUACUGUUUCCCUu 5' hsa-miR-211 } \\
\qquad|||||| \mid \\
\text { 5' ggauauuGAAUGUUAAAGGGAu 3' TP63 }\end{array}$ & microRNA.ORG miRDB \\
\hline hsa-miR-221 & $\begin{array}{l}\text { 3' cuuUGGGUCGUCUGUUACAUCGa 5' hsa-miR-221 } \\
\qquad|||||| \\
\text { 5' uauAGCUUGCAGA--ACUGUAGCu 3' TP63 }\end{array}$ & $\begin{array}{l}\text { microRNA.ORG DIANA- } \\
\text { MICROT }\end{array}$ \\
\hline hsa-miR-223 & $\begin{array}{l}\text { 3' acc ccAUAAACUGU--UUGACUGu 5' hsa-miR-223 } \\
\qquad|||||| \\
\text { 5' ugguaUAUUUUAUAUUACUGACa 3' TP63 }\end{array}$ & microRNA.ORG miRDB \\
\hline hsa-miR-224 & $\begin{array}{l}\text { 3' uugCCUUGGUGA--UCACUGAAc 5' hsa-miR-224 } \\
\qquad|||||||| \\
\text { 5' gcaGAGAUUUCUCAUUGACUUu 3' TP63 }\end{array}$ & $\begin{array}{l}\text { microRNA.ORG DIANA- } \\
\text { MICROT }\end{array}$ \\
\hline hsa-miR-23a & $\begin{array}{l}\text { 3' ccuuuagGGACCGUUACACUa 5' hsa-miR-23a } \\
\qquad|||||| \mid \\
\text { 5' ------gCCUCACCAUGUGAg 3' TP63 }\end{array}$ & microRNA.ORG miRDB \\
\hline hsa-miR-23b & $\begin{array}{l}\text { 3' ccauuagGGACCGUUACACUa 5' hsa-miR-23b } \\
\text { 5' ------gCCUCACCAUGUGAg 3' TP63 }\end{array}$ & microRNA.ORG miRDB \\
\hline hsa-miR-26a & $\begin{array}{l}\text { 3' ucggauaggaccuaaUGAACUu 5' hsa-miR-26a } \\
\qquad|||||| \\
\text { 5' gauuuccagaaccacACUUGAa 3' TP63 }\end{array}$ & microRNA.ORG Targetscan \\
\hline hsa-miR-26b & $\begin{array}{l}\text { 3' uggAUAGGACUU----AAUGAACUu 5' hsa-miR-26b } \\
\qquad \text { 5' ggaUUUCCAGAACCACACUUGAa 3' TP63 }^{\prime|||| \mid}\end{array}$ & microRNA.ORG Targetscan \\
\hline hsa-miR-30a & 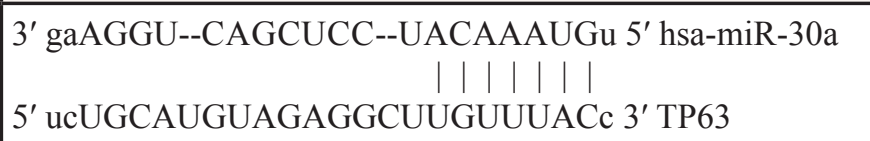 & microRNA.ORG miRDB \\
\hline hsa-miR-30b & $\begin{array}{l}\text { 3' ucGACUCACAUC--CU----ACAAAUGu 5' hsa-miR-30b } \\
\qquad|||||| \mid \\
\text { 5' cuCUGCAUGUAGAGGCUUGUUUACc 3' TP63 }\end{array}$ & microRNA.ORG miRDB \\
\hline hsa-miR-30c & $\begin{array}{l}\text { 3' cgacucucACAUC--CU----ACAAAUGu 5' hsa-miR-30c } \\
\qquad|||||| \mid \\
\text { 5' acucugcaUGUAGAGGCUUGUUUACc 3' TP63 }\end{array}$ & microRNA.ORG miRDB \\
\hline hsa-miR-30d & $\begin{array}{l}\text { 3' gaAGGU--CAGC--CCCUACAAAUGu 5' hsa-miR-30d } \\
\text { 5' ucUGCAUGUAGAGGCUUGUUUACc 3' TP63 }\end{array}$ & microRNA.ORG miRDB \\
\hline hsa-miR-30e & $\begin{array}{l}\text { 3' gaAGGU--CAGUUCC--UACAAAUGu 5' hsa-miR-30e } \\
\qquad|||||| \mid \\
\text { 5' ucUGCAUGUAGAGGCUUGUUUACc 3' TP63 }\end{array}$ & microRNA.ORG miRDB \\
\hline hsa-miR-301a & $\begin{array}{l}\text { 3' cgaaaCUGUUAUGAUAACGUGAc 5' hsa-miR-301a } \\
\qquad|||||| \mid \\
\text { 5' ugaaaGAAAAUUGAGUUGCACUu 3' TP63 }\end{array}$ & microRNA.ORG Targetscan \\
\hline hsa-miR-301b & $\begin{array}{l}\text { 3' cgaaaCUGUUAUAGUAACGUGAc 5' hsa-miR-301b } \\
\qquad|||||||| \\
\text { 5' ugaaaGAAAAUUGAGUUGCACUu 3' TP63 }\end{array}$ & microRNA.ORG Targetscan \\
\hline hsa-miR-302a & $\begin{array}{l}\text { 3' aguggUUUUGUACCU----UCGUGAAu 5' hsa-miR-302a } \\
\text { 5' augaaAGAAAAUUGAGUUGCACUUa 3' ТP63 }\end{array}$ & $\begin{array}{c}\text { microRNA.ORG miRtarBase } \\
\text { DIANA-MICROT }\end{array}$ \\
\hline
\end{tabular}

(Continued) 


\begin{tabular}{|c|c|c|}
\hline hsa-miR-302b & $\begin{array}{l}\text { 3' gaugaUUUUGUACCU----UCGUGAAu 5' hsa-miR-302b } \\
\qquad \text { 5' augaaAGAAAAUUGAGUUGCACUUa 3' TP63 }^{\prime}\end{array}$ & $\begin{array}{c}\text { microRNA.ORG miRtarBase } \\
\text { DIANA-MICROT }\end{array}$ \\
\hline hsa-miR-302c & $\begin{array}{l}\text { 3' ggugaCUUUGUAC--CUUCGUGAAu 5' hsa-miR-302c } \\
\qquad|||||| \\
\text { 5' ugaaaGAAAAUUGAGUUGCACUUa 3' TP63 }\end{array}$ & $\begin{array}{c}\text { microRNA.ORG miRtarBase } \\
\text { DIANA-MICROT }\end{array}$ \\
\hline hsa-miR-302d & $\begin{array}{l}\text { 3' ugugaguuuguaccuuCGUGAAu 5' hsa-miR-302d } \\
\qquad|||||| \\
\text { 5' gaaagaaaauugaguuGCACUUa 3' TP63 }\end{array}$ & $\begin{array}{c}\text { microRNA.ORG miRtarBase } \\
\text { DIANA-MICROT }\end{array}$ \\
\hline hsa-miR-302e & $\begin{array}{l}\text { 3' uucguaccuuCGUGAAu 5' hsa-miR-302e } \\
\qquad|||||| \\
\text { 5' aaauugaguuGCACUUa 3' TP63 }\end{array}$ & $\begin{array}{c}\text { microRNA.ORG miRtarBase } \\
\text { DIANA-MICROT }\end{array}$ \\
\hline hsa-miR-3163 & $\begin{array}{l}\text { 3' cagaaugacgggaguAAAAUAu 5' hsa-miR-3163 } \\
\text { 5' agauuucucauugacUUUUAUa 3' TP63 }\end{array}$ & miRDB DIANA-MICROT \\
\hline hsa-miR-32 & $\begin{array}{l}\text { 3' acguugaaucauuac ACGUUAu 5' hsa-miR-32 } \\
\qquad \text { 5' uuguuugccaggacaUGCAAUa 3' TP63 }\end{array}$ & $\begin{array}{l}\text { microRNA.ORG DIANA- } \\
\text { MICROT }\end{array}$ \\
\hline hsa-miR-340 & $\begin{array}{l}\text { 3' uuagucAGAG--UAA--CGAAAUAUu 5' hsa-miR-340 } \\
\qquad|||||| \mid \\
\text { 5' uauuuuUUUCUAUUAUUUUUAUAa 3' TP63 }\end{array}$ & $\begin{array}{c}\text { microRNA.ORG DIANA- } \\
\text { MICROT }\end{array}$ \\
\hline hsa-miR-3666 & $\begin{array}{l}\text { 3' agccguagaugugAACGUGAC 5' hsa-miR-3666 } \\
\qquad|||||||| \\
\text { 5' aaagaaaauugagUUGCACUU 3' TP63 }\end{array}$ & Targetscan DIANA-MICROT \\
\hline hsa-miR-371 & $\begin{array}{l}\text { 3' ucacgggggugucAAACUCa 5' hsa-miR-371-5p } \\
\qquad|||||| \\
\text { 5' gccacaucaaaccUUUGAGu 3' TP63 }\end{array}$ & $\begin{array}{l}\text { microRNA.ORG DIANA- } \\
\text { MICROT }\end{array}$ \\
\hline hsa-miR-374a & $\begin{array}{l}3^{\prime} \text { gugAAUAGUCCAACAUAAUAUu 5' hsa-miR-374a } \\
\qquad|||||||| \\
\text { 5' augUUUUCAAAAGGUAUUAUAc 5' TP63 }\end{array}$ & $\begin{array}{l}\text { microRNA.ORG DIANA- } \\
\text { MICROT }\end{array}$ \\
\hline hsa-miR-374b & $\begin{array}{l}\text { 3' gugAAUCGUCCAACAUAAUAUa 5' hsa-miR-374b } \\
\qquad|||||||| \\
\text { 5' augUUUUCAAAAGGUAUUAUAc 3' TP63 }\end{array}$ & $\begin{array}{l}\text { microRNA.ORG DIANA- } \\
\text { MICROT }\end{array}$ \\
\hline hsa-miR-377 & $\begin{array}{l}\text { 3' ugUUUUCA--ACG---------GAAACACACUa 5' hsa-miR-377 } \\
\qquad|||||||| \mid \\
\text { 5' ugAAAAGUGUGUAUAUAUUUUGUGUGAa 3' TP63 }\end{array}$ & $\begin{array}{c}\text { microRNA.ORG DIANA- } \\
\text { MICROT }\end{array}$ \\
\hline hsa-miR-454 & $\begin{array}{l}\text { 3' ugggaUAUUCGUUAUAACGUGAu 5' hsa-miR-454 } \\
\qquad|||||| \mid \\
\text { 5' gaaagAAAAUUGA--GUUGCACUu 3' TP63 }\end{array}$ & microRNA.ORG Targetscan \\
\hline hsa-miR-495 & $\begin{array}{l}\text { 3' uucUUCACGUGGUACAAACAAa 5' hsa-miR-495 } \\
\qquad|||||||| \\
\text { 5' gguAAGAGUUUCA--GUUUGUUg 3' TP63 }\end{array}$ & $\begin{array}{l}\text { microRNA.ORG DIANA- } \\
\text { MICROT }\end{array}$ \\
\hline hsa-mir-519a-3p & $\begin{array}{l}\text { 3' ugugagaUUUUCCU----ACGUGAAa 5' hsa-miR-519a } \\
\qquad|||||||| \\
\text { 5' ugaaagaAAAUUGAGUUGCACUUa 3' TP63 }\end{array}$ & $\begin{array}{c}\text { microRNA.ORG Targetscan } \\
\text { miRDB }\end{array}$ \\
\hline hsa-mir-519b-3p & $\begin{array}{l}\text { 3' uuggagaUUUUCCU--ACGUGAAa 5' hsa-miR-519b-3p } \\
\qquad|||||||| \\
\text { 5' ugaaagaAAAUUGAGUUGCAUUa 3' TP63 }\end{array}$ & $\begin{array}{c}\text { microRNA.ORG Targetscan } \\
\text { miRDB }\end{array}$ \\
\hline
\end{tabular}

(Continued) 


\begin{tabular}{|c|c|c|}
\hline hsa-mir-519c-3p & $\begin{array}{l}\text { 3' uaggagaUUU---UUCUACGUGAAa 5' hsa-miR-519c-3p } \\
\qquad|||||||||||| \mid \\
\text { 5' ugaagaAAAUUGAGUUGCACUUa 3'TP63 }\end{array}$ & $\begin{array}{c}\text { microRNA.ORG Targetscan } \\
\text { miRDB }\end{array}$ \\
\hline hsa-mir-519e & $\begin{array}{l}\text { 3' uugugagauuuuccuCCGUGAa 5' hsa-miR-519e } \\
\qquad|||||| \mid \\
\text { 5' gugucucauggauuuGGCACUa 3' TP63 }\end{array}$ & microRNA.ORG miRDB \\
\hline hsa-miR-520a & $\begin{array}{l}\text { 3' ugucagguuucccuuCGUGAAa } 5^{\prime} \text { hsa-miR-520a-3p } \\
\qquad|||||| \mid \\
\text { 5' aagaaaauugaguuGCACUUa } 33^{\prime} \text { TP63 }\end{array}$ & microRNA.ORG miRDB \\
\hline hsa-miR-520b & $\begin{array}{l}3^{\prime} \text { gggagauuuuccuuCGUGAAa } 5^{\prime} \text { ' hsa-miR-520b } \\
\text { 5' aagaaaauugaguuGCACUUa 3' TP63 }\end{array}$ & microRNA.ORG miRDB \\
\hline hsa-miR-520c & $\begin{array}{l}\text { 3' ugggagauuuuccuuCGUGAAa } 5^{\prime} \text { hsa-miR-520c-3p } \\
\qquad|||||| \mid \\
\text { 5' aagaaaauugaguuGCACUUa } 3{ }^{\prime} \text { TP63 }\end{array}$ & microRNA.ORG miRDB \\
\hline hsa-miR-520d & $\begin{array}{l}\text { 3' uggguggUUU----CUCUUCGUGAAa 5' hsa-miR-520d-3p } \\
\qquad|||||| \mid \\
\text { 5' ugaaagaAAAUUGAGUUGCACUUa 3' TP63 }\end{array}$ & microRNA.ORG miRDB \\
\hline hsa-miR-520e & $\begin{array}{l}\text { 3' gggaguuuuuccuuCGUGAAa 5' hsa-miR-520e } \\
\qquad|||||| \\
\text { 5' aagaaaauugaguuGCACUUa 3' TP63 }\end{array}$ & microRNA.ORG miRDB \\
\hline hsa-miR-524 & $\begin{array}{l}\text { 3' cucuuucacgAAG--GGAAACAUc 5'hsa-miR-524-5p } \\
\qquad|||||||| \\
\text { 5' gaaccauaaaUUCAACUUUGUAa 3' TP63 }\end{array}$ & miRDB DIANA-MICROT \\
\hline hsa-miR-539 & $\begin{array}{l}\text { 3' ugUGUGGUUCCUAUUAAAGAGg 5' hsa-miR-539 } \\
\qquad|||||||| \\
\text { 5' uuAAGCUGCAGA--GAUUUCUCa 3' TP63 }\end{array}$ & $\begin{array}{l}\text { microRNA.ORG DIANA- } \\
\text { MICROT }\end{array}$ \\
\hline hsa-miR-543 & $\begin{array}{l}\text { 3' uucUUCA--CGUGGCGCUUACAAa 5' hsa-miR-543 } \\
\qquad|||||||||| \\
\text { 5' aguAUGUGGGAUAUUGAAUGUUa 3' TP63 }\end{array}$ & microRNA.ORG miRDB \\
\hline hsa-miR-590-3p & $\begin{array}{l}\text { 3' ugaucgaaUAUGUAUUUUAAu 5' hsa-miR-590-3p } \\
\qquad|||||||| \mid \\
\text { 5' gauuugaaAAAUAUAAAAUUa 3' TP63 }\end{array}$ & microRNA.ORG miRDB \\
\hline hsa-miR-630 & $\begin{array}{l}\text { 3' uggaagGGACCAUGUCUUAUGa 5' hsa-miR-630 } \\
\qquad|||||||| \mid \\
\text { 5' auaccaUUUAGUA--AGAAUACc 3' TP63 }\end{array}$ & RNA22-HSA \\
\hline hsa-miR-875 & $\begin{array}{l}\text { 3' gugGACUAUUUUGACUCCAUAu 5' hsa-miR-875-5p } \\
\text { 5' uugCUGCCAUUACAGAGGUAUu 3' TP63 }\end{array}$ & microRNA.ORG miRDB \\
\hline hsa-miR-885-3p & $\begin{array}{l}\text { 3' auaggugaUGUGGGGCGACGGa 5' hsa-miR-885-3p } \\
\qquad|||||||| \\
\text { 5'uugggaaaACA--UUUGCUGCCa 3' TP63 }\end{array}$ & $\begin{array}{l}\text { RNA22-HSA } \\
\text { microRNA.ORG }\end{array}$ \\
\hline hsa-miR-92a & $\begin{array}{l}\text { 3' ugucCGGCCCUGUUCACGUUAu 5' hsa-miR-92a } \\
\text { 5' guuuGCCAGGAC----AUGCAAUa 3' TP63 }\end{array}$ & $\begin{array}{l}\text { microRNA.ORG miRtarBase } \\
\text { DIANA-MICROT }\end{array}$ \\
\hline hsa-miR-92b & $\begin{array}{l}\text { 3' ccucCGGCCCUGCUCACGUUAu 5' hsa-miR-92b } \\
\qquad|||||||| \mid \\
\text { 5' guuuGCCAGGAC---AUGCAAUa 3' TP63 }\end{array}$ & $\begin{array}{l}\text { microRNA.ORG miRtarBase } \\
\text { DIANA-MICROT }\end{array}$ \\
\hline
\end{tabular}


Table 4: The promoters of miRNAs contain p53/p63-REs

\begin{tabular}{|c|c|c|c|}
\hline \multirow[t]{2}{*}{ miRNAName } & TFSEARCH p53/p63-REs & $\begin{array}{c}\text { JASPAR datasetsp53/ } \\
\text { p63-REs }\end{array}$ & \multirow[t]{2}{*}{ predicted site sequence } \\
\hline & Scores & Scores & \\
\hline hsa-miR-1297 & 67.1 & 10.384 & ATTCATGTGCTCACCAGCAT \\
\hline \multirow[t]{3}{*}{ hsa-miR-130a } & 62.2 & 10.215 & GGTCCTGTCCTCCCATGCCA \\
\hline & & 8.413 & GGGGAGGCACTGGCAGGCCT \\
\hline & & 6.776 & GGCCCCGCCCCAGCCAGCCT \\
\hline hsa-miR-130b & None & None & None \\
\hline hsa-miR-133b & 63.8 & 7.731 & СССССТGCTCTGGCTGGTCA \\
\hline \multirow[t]{2}{*}{ hsa-miR-136 } & 60.9 & 7.980 & AGCCTGGCTCTTTCTTGCAT \\
\hline & & 6.143 & ATCCTGGCACCCACAGGTTC \\
\hline \multirow[t]{3}{*}{ hsa-miR-140 } & 62.9 & 7.719 & ATGCCTGTTCATACAGACAG \\
\hline & & 6.521 & СCTCCCGCCCCTGCCTGCTG \\
\hline & & 6.205 & TGGTAGGTTACGTCATGCTG \\
\hline hsa-miR-149 & 70 & 7.225 & TGAGATGCCGTGGCCGGTCC \\
\hline \multirow[t]{2}{*}{ hsa-miR-181a } & 60.9 & 11.661 & TTACATGTGCCACCCTGCCT \\
\hline & & 11.511 & ATGTGTGCTCAAACTTGCTT \\
\hline \multirow[t]{4}{*}{ hsa-miR-181b } & 60.9 & 8.519 & AAACAGGACGTAGCAAGTAA \\
\hline & & 6.827 & TTACTAGTGCCCACATATCC \\
\hline & & 6.616 & TCTAATGTACCTACATGTCT \\
\hline & & 6.382 & TTACAGGTACTAATATGCAA \\
\hline hsa-miR-181c & 67.8 & 9.772 & AGGCCAGCACTCCССТGCAC \\
\hline \multirow[t]{2}{*}{ hsa-miR-181d } & 67.8 & 9.772 & AGGCCAGCACTCCСCTGCAC \\
\hline & & 6.779 & AATCCAGCCTGGGCACGTCC \\
\hline hsa-miR-186 & None & None & None \\
\hline \multirow[t]{2}{*}{ hsa-miR-203 } & 63.8 & 10.527 & GCGCTGGTCCTCACCTGTTC \\
\hline & & 6.155 & GGGTGTGTCCAGCCCAGCCC \\
\hline hsa-miR-204 & 60.9 & None & None \\
\hline hsa-miR-21 & 60.6 & None & None \\
\hline hsa-miR-211 & 60.9 & None & None \\
\hline hsa-miR-221 & 61.6 & 8.541 & GTACCAGTGCACTCCAGCCT \\
\hline hsa-miR-223 & None & None & None \\
\hline hsa-miR-224 & 61.6 & 7.065 & GCCCCTGCCCATCCAAGCTC \\
\hline hsa-miR-23a & 70.7 & 10.796 & AGCCATGATCACACCAGCCT \\
\hline hsa-miR-23b & 61.2 & 7.873 & ATTTTTGCCCAGGCAGGCAA \\
\hline hsa-miR-26a & None & 6.504 & AGGCATGCTTCATCATCCTC \\
\hline \multirow[t]{3}{*}{ hsa-miR-26b } & 61.8 & 8.511 & ACACCTGGGCACACATGCAG \\
\hline & & 6.475 & ATGCAGGATTCTGCAGGCCA \\
\hline & & 6.258 & CGGCAAGATCCTCCTGGCTC \\
\hline
\end{tabular}

(Continued) 


\begin{tabular}{|c|c|c|c|}
\hline \multirow[t]{2}{*}{ miRNAName } & TFSEARCH p53/p63-REs & $\begin{array}{c}\text { JASPAR datasetsp53/ } \\
\text { p63-REs }\end{array}$ & \multirow[t]{2}{*}{ predicted site sequence } \\
\hline & Scores & Scores & \\
\hline \multirow[t]{2}{*}{ hsa-miR-30a } & 66.8 & 8.706 & AAAAATGTACAGACATGGTT \\
\hline & & 7.945 & TCTCATGGCCCAGCATGACT \\
\hline \multirow[t]{3}{*}{ hsa-miR-30b } & 61.2 & 8.073 & ATTCAAGTAGATCCCTGCCA \\
\hline & & 8.032 & GAGCATACAGACACTTGCCA \\
\hline & & 7.230 & AGGCAAGAGCATACAGACAC \\
\hline hsa-miR-30c & 60.3 & 8.774 & ATGCAAGTGCAAAAATGTAT \\
\hline hsa-miR-30d & None & None & None \\
\hline hsa-miR-30e & 69.7 & None & None \\
\hline hsa-miR-301a & 64.2 & None & None \\
\hline hsa-miR-301b & 70.7 & None & None \\
\hline \multirow[t]{4}{*}{ hsa-miR-302a } & 62.5 & 10.060 & AAGCAAGTACATCCACGTTT \\
\hline & & 9.027 & AAATAAGCCCATTCCAGCCT \\
\hline & & 8.869 & CAGCAAGTGCCTCCATGTTA \\
\hline & & 7.824 & TGTCATGTCACAGCAAGTGC \\
\hline \multirow[t]{5}{*}{ hsa-miR-302b } & None & 10.060 & AAGCAAGTACATCCACGTTT \\
\hline & & 9.027 & AAATAAGCCCATTCCAGCCT \\
\hline & & 8.869 & CAGCAAGTGCCTCCATGTTA \\
\hline & & 8.339 & CAGCAGGTACCCCCATGTTA \\
\hline & & 7.824 & TGTCATGTCACAGCAAGTGC \\
\hline \multirow[t]{5}{*}{ hsa-miR-302c } & 62.5 & 10.060 & AAGCAAGTACATCCACGTTT \\
\hline & & 9.027 & AAATAAGCCCATTCCAGCCT \\
\hline & & 8.869 & CAGCAAGTGCCTCCATGTTA \\
\hline & & 8.339 & CAGCAGGTACCCCCATGTTA \\
\hline & & 7.824 & TGTCATGTCACAGCAAGTGC \\
\hline hsa-miR-302d & None & None & None \\
\hline hsa-miR-302e & None & None & None \\
\hline hsa-miR-3163 & None & None & None \\
\hline hsa-miR-32 & None & None & None \\
\hline \multirow[t]{5}{*}{ hsa-miR-340 } & 64.8 & 8.837 & CTGCCGGTGGCAACATGTAG \\
\hline & & 7.456 & AGACAGGTCCAGGCTTCAAC \\
\hline & & 7.255 & AGGCATGGTGGCACATGTCT \\
\hline & & 7.034 & CACCAAGTAGGAACATGTAA \\
\hline & & 6.992 & TCTTATGTCCAGACTTGAGT \\
\hline hsa-miR-3666 & None & None & None \\
\hline hsa-miR-371 & 60.9 & None & None \\
\hline hsa-miR-374a & 62.2 & 12.317 & AAACATGTCTTAGCTGGCTT \\
\hline hsa-miR-374b & 60.3 & 6.258 & AGGCATGTGCCACCACACCT \\
\hline
\end{tabular}

(Continued) 


\begin{tabular}{|c|c|c|c|}
\hline \multirow[t]{2}{*}{ miRNAName } & TFSEARCH p53/p63-REs & $\begin{array}{c}\text { JASPAR datasetsp53/ } \\
\text { p63-REs }\end{array}$ & \multirow[t]{2}{*}{ predicted site sequence } \\
\hline & Scores & Scores & \\
\hline \multirow[t]{2}{*}{ hsa-miR-377 } & 68.4 & 10.889 & GTCCATGACCAACCATGTTC \\
\hline & & 6.431 & GGTCGTGCACCTGCAGGCGT \\
\hline \multirow[t]{2}{*}{ hsa-miR-454 } & None & 8.404 & TGGCCAGTACTGGCTTATTA \\
\hline & & 7.502 & AGGCGTGCACCACCATACCC \\
\hline \multirow[t]{2}{*}{ hsa-miR-495 } & 66.1 & 8.931 & AGGCAAGGAGATGCTTGCTG \\
\hline & & 7.293 & TTACTTGTTTAAGCCAGTTG \\
\hline hsa-miR-519a-3p & None & None & None \\
\hline hsa-miR-519b-3p & None & None & None \\
\hline hsa-miR-519c-3p & None & None & None \\
\hline hsa-miR-519e & None & None & None \\
\hline hsa-miR-520a & None & None & None \\
\hline \multirow[t]{4}{*}{ hsa-miR-520b } & 66.4 & 15.207 & AGGCATGTGCTACCATGCCC \\
\hline & & 7.330 & AGGCATGCACCACCACACCT \\
\hline & & 7.330 & AGGCATGCACCACCACACCT \\
\hline & & 6.271 & TTTTTTGTACAGACATGGTT \\
\hline hsa-miR-520c & 60.4 & 11.688 & TCTCAGGTTCAAGCAAGTCT \\
\hline hsa-miR-520d & None & None & None \\
\hline \multirow[t]{3}{*}{ hsa-miR-520e } & 61.6 & 8.184 & AGGCGTGAGCTACCCTGCCC \\
\hline & & 7.625 & GCTCAAGCATCCTCCTGCCT \\
\hline & & 7.028 & TGGTGTGCAGTGTCATGTTC \\
\hline \multirow[t]{3}{*}{ hsa-miR-524 } & 66.4 & 11.360 & AGGCACGCACCGCCATGCCG \\
\hline & & 8.473 & GCGCAGGTGCACTCCAGCCT \\
\hline & & 6.384 & TTACAAGCACCCACCAACAC \\
\hline \multirow[t]{3}{*}{ hsa-miR-539 } & 64.2 & 11.098 & GAACGAGTTAAGACTTGTAC \\
\hline & & 7.204 & CACCACGCACACACAGGCAT \\
\hline & & 6.519 & GGGCAAGGGCTGGCATGGAG \\
\hline hsa-miR-543 & 62.5 & 14.784 & ACGCCTGCCCTGTCCTGCAC \\
\hline hsa-miR-590 & 64.2 & 9.773 & CAGGGTGCCCAGGCATGCAA \\
\hline hsa-miR-630 & None & None & None \\
\hline hsa-miR-875 & None & 7.726 & CAGCCAGCCCCCTCATATCC \\
\hline hsa-miR-885-3p & None & None & None \\
\hline \multirow[t]{5}{*}{ hsa-miR-92a } & 70.7 & 12.995 & GCACTTGTCCCGGCCTGTTG \\
\hline & & 8.804 & ACTCCAGCTTCGGCCTGTCG \\
\hline & & 7.105 & GAGCTTATTTAGACATGTAT \\
\hline & & 6.601 & TGACAAGTTCATTCTTCTCT \\
\hline & & 6.189 & ATGCAATTCCTTACCTGTAA \\
\hline hsa-miR-92b & 60.6 & 7.510 & GTTCAAGACCAGCCTGGCCA \\
\hline
\end{tabular}


predominately present, will vary for individual tumors, and it remains to be seen how dependent these relationships are on cancer progress. It has become increasingly clear that p63 and miRNAs are linked in a novel autoregulatory feedback loop that controls tumorigenesis.

It is now apparent that many tumors are dependent upon a dysregulation of $\mathrm{p} 63$ and miRNAs, providing a rationale for therapeutic intervention of $\mathrm{p} 63$ and miRNAs. Therefore, the p63/miRNA network represents a novel approach for treatment and is likely to lead to new therapeutic anticancer strategies.

\section{ACKNOWLEDGMENTS}

This work was supported by the Key Program for International Cooperation Projects of Hunan Province (no. 2011WK2011) and the Natural Science Foundation of China (No. 81172298).

\section{CONFLICT OF INTEREST}

The authors declare no conflict of interest.

\section{REFERENCES}

1. Carpenter S, Ricci EP, Mercier BC, Moore MJ, Fitzgerald KA. Post-transcriptional regulation of gene expression in innate immunity. Nat Rev Immunol. 2014; 14:361-76. doi: 10.1038/nri3682.

2. Smale ST. Transcriptional regulation in the innate immune system. Curr Opin Immunol. 2012; 24:51-7. doi: 10.1016/j. coi.2011.12.008.

3. Neilsen PM, Noll JE, Suetani RJ, Schulz RB, Al-Ejeh F, Evdokiou A, Lane DP, Callen DF. Mutant p53 uses p63 as a molecular chaperone to alter gene expression and induce a pro-invasive secretome. Oncotarget. 2011; 2:1203-17.

4. Sive JI, Göttgens B. Transcriptional network control of normal and leukaemic haematopoiesis. Exp Cell Res. 2014; pii:S0014-4827 00268-7. doi: 10.1016/j.yexcr.2014.06.021.

5. Blandino G, Fazi F, Donzelli S, Kedmi M, Sas-Chen A, Muti P, Strano S6, Yarden Y. Tumor suppressor microRNAs: a novel non-coding alliance against cancer. FEBS Lett. 2014; 588:2639-52. doi: 10.1016/j. febslet.2014.03.033.

6. Levine AJ, Tomasini R, McKeon FD, Mak TW, Melino G. The p53 family: guardians of maternal reproduction. Nat Rev Mol Cell Biol. 2011; 12:259-65. doi: 10.1038/nrm3086.

7. Finlan LE, Hupp TR. p63: the phantom of the tumor suppressor. Cell Cycle. 2007; 6:1062-71.

8. Khoury MP, Bourdon JC. p53 Isoforms: An Intracellular Microprocessor? Genes Cancer. 2011; 2:453-65. doi: $10.1177 / 1947601911408893$

9. Moll UM, Slade N. p63 and p73: roles in development and tumor formation. Mol Cancer Res. 2004; 2:371-86.
10. Vanbokhoven H, Melino G, Candi E, Declercq W. p63, a story of mice and men. J Invest Dermatol. 2011; 131:1196207. doi: 10.1038/jid.2011.84.

11. Perez CA, Pietenpol JA. Transcriptional programs regulated by p3 in normal epithelium and tumors. Cell Cycle. 2007; 6:246-54.

12. Guo X, Mills AA. p63, cellular senescence and tumor development. Cell Cycle. 2007; 6:305-11.

13. Karni-Schmidt O, Castillo-Martin M, Shen TH, Gladoun N, Domingo-Domenech J, Sanchez-Carbayo M, Li Y, Lowe S, Prives C, Cordon-Cardo C. Distinct expression profiles of p63 variants during urothelial development and bladder cancer progression. Am J Pathol. 2011; 178:1350-60.

14. Mitani Y, Li J, Weber RS, Lippman SL, Flores ER, Caulin C, El-Naggar AK. Expression and regulation of the $\triangle \mathrm{N}$ and TAp63 isoforms in salivary gland tumorigenesis clinical and experimental findings. Am J Pathol. 2011; 179:391-9. doi: 10.1016/j.ajpath.2011.03.037.

15. Truong A, Kretz M, Ridky T, Kimmel R, Khavari P. p63 regulates prolilferation and differentiation of developmentally mature keratinocytes. Genes \& Dev. 2006; 20:3185-97.

16. Massion P, Taflan P, Jamshedur Rahman S, Yildiz P, Shyr Y, Edgerton M, Westfall M, Roberts J, Pietenpol J, Carbone D, Gonzalez A. Significance of p63 amplification and overexpression in lung cancer development and prognosis. Cancer Res. 2003; 63:7113-21.

17. Wu J, Liang S, Bergholz J, He H, Walsh EM, Zhang Y, Xiao ZX. $\triangle \mathrm{Np} 63 \alpha$ activates CD82 metastasis suppressor to inhibit cancer cell invasion. Cell Death Dis. 2014; 5:e1280. doi: 10.1038/cddis.2014.239.

18. Bid HK, Roberts RD, Cam M, Audino A, Kurmasheva RT, Lin J, Houghton PJ, Cam H. $\triangle \mathrm{Np} 63$ promotes pediatric neuroblastoma and osteosarcoma by regulating tumor angiogenesis. Cancer Res. 2014; 74:320-9. doi: 10.1158/0008-5472. CAN-13-0894.

19. Moergel M, Goldschmitt J, Stockinger M, Kunkel M. $\triangle$ Np63 expression in four carcinoma cell lines and the effect on radioresistance - a siRNA knockdown model. Clin Oral Investig. 2014; 18:1259-68. doi: 10.1007/ s00784-013-1078-0.

20. Dötsch V, Bernassola F, Coutandin D, Candi E, Melino G. p63 and p73, the ancestors of p53. Cold Spring Harb Perspect Biol. 2010; 2:a004887. doi: 10.1101/cshperspect.a004887.

21. DeYoung MP, Ellisen LW. p63 and p73 in human cancer: defining the network. Oncogene. 2007; 26:5169-5183.

22. Yao JY, Chen JK. Roles of p63 in Epidermal Development and Tumorigenesis. Biomed, J. 2012; 35:457-63. doi: 10.4103/2319-4170.104410.

23. Ratovitski EA. Tumor Protein p63/microRNA Network in Epithelial Cancer Cells. Curr Genomics. 2013; 14:441-52. doi: 10.2174/13892029113146660011.

24. Ghioni P, Bolognese F, Duijf PH, Van Bokhoven H, Mantovani R, Guerrini L. Complex transcriptional effects 
of p63 isoforms: identification of novel activation and repression domains. Mol Cell Biol. 2002; 22:8659-68.

25. Helton ES, Zhu J, Chen X. The unique NH2-terminally deleted (DeltaN) residues, the PXXP motif, and the PPXY motif are required for the transcriptional activity of the DeltaN variant of p63. J Biol Chem. 2006; 281:2533-42.

26. Su X, Chakravarti D, Cho MS, Liu L, Gi YJ, Lin YL, Leung ML, El-Naggar A, Creighton CJ, Suraokar MB, Wistuba I, Flores ER. TAp63 suppresses metastasis through coordinate regulation of Dicer and miRNAs. Nature. 2010; 467:986-990.

27. Tucci P, Agostini M, Grespi F, Markert EK, Terrinoni A, Vousden KH, Muller PA, Do "tsch V, Kehrloesser S, Sayan BS, Giaccone G, Lowe SW, Takahashi N, et al. Loss of p63 and its microRNA-205 target results in enhanced cell migration and metastasis in prostate cancer. Proc Natl Acad Sci U S A. 2012; 109:15312-7.

28. Lagos-Quintana M, Rauhut R, Lendeckel W, Tuschl T. Identification of novel genes coding for small expressed RNAs. Science. 2001; 294:853-8.

29. Esquela-Kerscher A, Slack FJ. Oncomirs - microRNAs with a role in cancer. Nat Rev Cancer. 2006; 6:259-69.

30. Khare S, Zhang Q, Ibdah JA. Epigenetics of hepatocellular carcinoma: Role of microRNA. World J Gastroenterol. 2013; 19:5439-45. doi: 10.3748/wjg.v19.i33.5439.

31. Kinose Y, Sawada K, Nakamura K, Kimura T. The role of microRNAs in ovarian cancer. Biomed Res Int. 2014; 2014:249393. doi: 10.1155/2014/249393.

32. Soon P, Kiaris H. MicroRNAs in the tumour microenvironment: big role for small players. Endocr Relat Cancer. 2013; 20:R257-67. doi: 10.1530/ERC-13-0119.

33. Li CH, Xu F, Chow S, Feng L, Yin D, Ng TB, Chen Y. Hepatitis B virus $\mathrm{X}$ protein promotes hepatocellular carcinoma transformation through interleukin- 6 activation of microRNA-21 expression. Eur J Cancer. 2014; pii: S09598049(14)00807-7. doi: 10.1016/j.ejca.2014.07.008.

34. Müller V, Gade S, Steinbach B, Loibl S, von Minckwitz G, Untch M, Schwedler K, Lübbe K, Schem C, Fasching PA, Mau C, Pantel K, Schwarzenbach H. Changes in serum levels of miR-21, miR-210, and miR-373 in HER2-positive breast cancer patients undergoing neoadjuvant therapy: a translational research project within the Geparquinto trial. Breast Cancer Res Treat. 2014; 147:61-8. doi: 10.1007/ s10549-014-3079-3.

35. Gwak JM, Kim HJ, Kim EJ, Chung YR, Yun S, Seo AN, Lee HJ, Park SY. MicroRNA-9 is associated with epithelial-mesenchymal transition, breast cancer stem cell phenotype, and tumor progression in breast cancer. Breast Cancer Res Treat. 2014; 147:39-49. doi: 10.1007/ s10549-014-3069-5.

36. Bourguignon LY, Shiina M, Li JJ. Hyaluronan-CD44 Interaction Promotes Oncogenic Signaling, microRNA Functions, Chemoresistance, and Radiation Resistance in Cancer Stem Cells Leading to Tumor Progression. Adv Cancer Res. 2014; 123:255-75. doi: 10.1016/ B978-0-12-800092-2.00010-1.
37. Wei D, Wan Q, Li L, Jin H, Liu Y, Wang Y, Zhang G. MicroRNAs as Potential Biomarkers for Diagnosing Cancers of Central Nervous System: a Meta-analysis. Mol Neurobiol. 2014; http://dx.doi.org/10.1007/s12035-014-8822-6.

38. Finnegan EF, Pasquinelli AE. MicroRNA biogenesis: regulating the regulators. Crit Rev Biochem Mol Biol. 2013; 48:51-68. doi: 10.3109/10409238.2012.738643.

39. Ye S, Yang L, Zhao X, Song W, Wang W, Zheng S. Bioinformatics Method to Predict Two Regulation Mechanism: TF-miRNA-mRNA and lncRNA-miRNAmRNA in Pancreatic Cancer. Cell Biochem Biophys. 2014; 70:1849-58. doi: 10.1007/s12013-014-0142-y.

40. Liao JM, Zhou X, Zhang Y, Lu H. MiR-1246: a new link of the p53 family with cancer and Down syndrome. Cell Cycle. 2012; 11:2624-30. doi: 10.4161/cc.20809.

41. Boominathan L. The guardians of the genome ( $\mathrm{p} 53$, TA-p73, and TA-p63) are regulators of tumor suppressor miRNAs network. Cancer Metastasis Rev. 2010; 29:61339. doi: 10.1007/s10555-010-9257-9.

42. Blandino G, Moll UM. p63 regulation by microRNAs. Cell Cycle. 2009; 8:1466-7.

43. Piccolo S, Enzo E, Montagner M. p63, Sharp1, and HIFs: master regulators of metastasis in triple-negative breast cancer. Cancer Res. 2013; 73:4978-81. doi: 10.1158/00085472.CAN-13-0962.

44. Celardo I, Antonov A, Amelio I, AnnicchiaricoPetruzzelli M, Melino G. p63 transcriptionally regulates the expression of matrix metallopeptidase 13. Oncotarget. 2014; 5:1279-89.

45. Cui R, He J, Mei R, de Fromentel CC, Martel-Planche G, Taniere $\mathrm{P}$, Hainaut P. Expression of p53, p63, and p73 isoforms in squamous cell carcinoma and adenocarcinoma of esophagus. Biochem Biophys Res Commun. 2005; 336:339-345.

46. Mills AA. p63: Oncogene or tumor suppressor? Curr Opin Genet Dev. 2006; 16:38-44.

47. Vaughan CA, Singh S, Windle B, Yeudall WA, Frum R, Grossman SR, Deb SP, Deb S. Gain-of-Function Activity of Mutant p5 in Lung Cancer through Up-Regulation of Receptor Protein Tyrosine Kinase Axl. Genes Cancer. 2012; 3:491-502. doi: 10.1177/1947601912462719.

48. Melio I, Grespi F, Annicchiarico-Petruzzelli M, Melino G. p63 the guardian of human reproduction. Cell Cycle. 2012; 11:4545-51. doi: 10.4161/cc.22819.

49. Bernassola F, Oberst A, Melino G, Pandolfi PP. The promyelocytic leukaemia protein tumour suppressor functions as a transcriptional regulator of p63. Oncogene. 2005; 24:6982-6.

50. Carroll DK, Carroll JS, Leong CO, Cheng F, Brown M, Mills AA, Brugge JS, Ellisen LW. p63 regulates an adhesion programme and cell survival in epithelial cells. Nat Cell Biol. 2006; 8:551-561.

51. Senoo M, Pinto F, Crum CP, McKeon F. p63 is essential for the proliferative potential of stem cells in stratified epithelia. Cell. 2007; 129:523-536. 
52. Crook T, Nicholls JM, Brooks L, O’Nions J, Allday MJ. High level expression of DNV p63: a mechanism for the inactivation of p53 in undifferentiated nasopharyngeal carcinoma (NPC)? Oncogene. 2000; 19:3439-44.

53. Suarez-Carmona M, Hubert P, Gonzalez A, Duray A, Roncarati P, Erpicum C, Boniver J, Castronovo V, Noel A, Saussez S, Peulen O, Delvenne P, Herfs M. $\Delta$ Np63 isoformmediated $\beta$-defensin family up-regulation is associated with (lymph)angiogenesis and poor prognosis in patients with squamous cell carcinoma. Oncotarget. 2014; 5:1856-68.

54. Ram Kumar RM, Betz MM, Robl B, Born W, Fuchs B. $\Delta \mathrm{Np} 63 \alpha$ enhances the oncogenic phenotype of osteosarcoma cells by inducing the expression of GLI2. BMC Cancer. 2014; 14:559. doi: 10.1186/1471-2407-14-559.

55. Cui R, He J, Mei R, de Fromentel CC, Martel-Planche G, Taniere P, Hainaut P. Expression of p53, p63, and p73 isoforms in squamous cell carcinoma and adenocarcinoma of esophagus: Biochem Biophys Res Commun. 2005; 336:339-345.

56. Chung J, Irwin MS. Targeting the p53-family in cancer and chemosensitivity: triple threat. Curr Drug Targets. 2010; 11:667-81.

57. Alexandrova EM, Moll UM. Role of $\mathrm{p}$ family members p73 and p63 in human hematological malignancies. Leuk Lymphoma. 2012; 53:2116-29. doi: 10.3109/10428194.2012.684348.

58. Levrero M, De Laurenzi V, Costanzo A, Gong J, Wang JY, Melino G. The p53/p63/p73 family of transcription factors: overlapping and distinct functions. J Cell Sci. 2000; 113:1661-70.

59. Scoumanne A, Harms KL, Chen X. Structural basis for gene activation by $\mathrm{p} 53$ family members. Cancer Biol Ther. 2005; 4:1178-85.

60. Candi E, Dinsdale D, Rufini A, Salomoni P, Knight RA, Mueller M, Krammer PH, Melino G. TAp3 and DeltaNp3 in cancer and epidermal development. Cell Cycle. 2007; 6:274-85.

61. Gressner O, Schilling T, Lorenz K, Schulze Schleithoff E, Koch A, Schulze-Bergkamen H, Lena AM, Candi E, Terrinoni A, Catani MV, Oren M, Melino G, Krammer PH, et al. TAp63alpha induces apoptosis by activating signaling via death receptors and mitochondria. EMBO J. 2005; 24:2458-2471.

62. Liefer KM, Koster MI, Wang XJ, Yang A, McKeon F, Roop DR. Down-regulation of p63 is required for epidermal UV-B-induced apoptosis. Cancer Res. 2000; 60:4016-4020.

63. Mattiske S1, Ho K, Noll JE, Neilsen PM, Callen DF, Suetani RJ. TAp63 regulates oncogenic miR-155 to mediate migration and tumour growth. Oncotarget. 2013; 4:1894-903.

64. Herfs M, Hubert P, Suarez-Carmona M, Reschner A, Saussez S, Berx G, Savagner P, Boniver J, Delvenne P. Regulation of p63 isoforms by snail and slug transcription factors in human squamous cell carcinoma. Am J Pathol. 2010; 176:1941-9. doi: 10.2353/ajpath.2010.090804.
65. Cam M, Bid HK, Xiao L, Zambetti GP, Houghton PJ, Cam H. p53/TAp63 and AKT regulate mammalian target of rapamycin complex 1 (mTORC1) signaling through two independent parallel pathways in the presence of DNA damage. J Biol Chem. 2014; 289:4083-94. doi: 10.1074/ jbc.M113.530303.

66. D'Alessandro A, Amelio I, Berkers CR, Antonov A, Vousden KH, Melino G, Zolla L. Metabolic effect of TAp63 $\alpha$ : enhanced glycolysis and pentose phosphate pathway, resulting in increased antioxidant defense. Oncotarget. 2014; 5:7722-33.

67. Giacobbe A, Bongiorno-Borbone L, Bernassola F, Terrinoni A, Markert EK, Levine AJ, Feng Z, Agostini M, Zolla L, Agrò AF, Notterman DA, Melino G, Peschiaroli A. p63 regulates glutaminase 2 expression. Cell Cycle. 2013; 12:1395-405. doi: 10.4161/cc.24478.

68. Garofalo M, Croce CM. Role of microRNAs in maintaining cancer stem cells. Adv Drug Deliv Rev. 2014; pii: S0169409X(14)00277-4. doi: 10.1016/j.addr.2014.11.014.

69. Callegari E, Gramantieri L, Domenicali M, D’Abundo L, Sabbioni S, Negrini M. MicroRNAs in liver cancer: a model for investigating pathogenesis and novel therapeutic approaches. Cell Death Differ. 2014; doi: 10.1038/ cdd.2014.136.

70. Kozomara A, Griffiths-Jones S. miRBase: annotating high confidence microRNAs using deep sequencing data. NAR. 2014; 42:D68-D73.

71. Kozomara A, Griffiths-Jones S. miRBase: integrating microRNA annotation and deep-sequencing data. NAR. 2011; 39:D152-D157.

72. Callegari E, Gramantieri L, Domenicali M, D'Abundo L, Sabbioni S, Negrini M. The complexity of miRNA-mediated repression. Cell Death Differ. 2014; doi: 10.1038/ cdd.2014.112.

73. Friedman RC1, Farh KK, Burge CB, Bartel DP. Most mammalian mRNAs are conserved targets of microRNAs. Genome Res. 2009; 19:92-105. doi: 10.1101/ gr.082701.108.

74. Zen K, Zhang CY. Circulating MicroRNAs: a novel class of biomarkers to diagnose and monitor human cancers. Med Res Rev. 2012; 32:326-48.

75. Andersen HH, Duroux M, Gazerani P. MicroRNAs as modulators and biomarkers of inflammatory and neuropathic pain conditions. Neurobiol Dis. 2014; pii: S09699961(14)00232-0. doi: 10.1016/j.nbd.2014.08.003.

76. Hogg DR, Harries LW. Human genetic variation and its effect on miRNA biogenesis, activity and function. Biochem Soc Trans. 2014; 42:1184-9. doi: 10.1042/ BST20140055.

77. Song SJ, Pandolfi PP. MicroRNAs in the pathogenesis of myelodysplastic syndromes and myeloid leukaemia. Curr Opin Hematol. 2014; 21:276-82. doi: 10.1097/ MOH.0000000000000054. 
78. Srivastava SK, Arora S, Singh S, Bhardwaj A, Averett C, Singh AP. MicroRNAs in pancreatic malignancy: progress and promises. Cancer Lett. 2014; 347:167-74. doi: 10.1016/j.canlet.2014.02.015.

79. Nikaki A, Piperi C, Papavassiliou AG. Role of microRNAs in gliomagenesis: targeting miRNAs in glioblastoma multiforme therapy. Expert Opin Investig Drugs. 2012; 21:1475-88.

80. Hummel R, Hussey DJ, Haier J. MicroRNAs: predictors and modifiers of chemo- and radiotherapy in different tumour types. Eur J Cancer. 2010; 46:298-311. doi: 10.1016/j.ejca.2009.10.027.

81. Daige CL, Wiggins JF, Priddy L, Nelligan-Davis T, Zhao J, Brown D. Systemic delivery of a miR-34a mimic as a potential therapeutic for liver cancer. Mol Cancer Ther. 2014; pii: molcanther.0209.2014.

82. Li J, Tan Q, Yan M, Liu L, Lin H, Zhao F, Bao G, Kong H, Ge C, Zhang F, Yu T, Li J, He X, Y et al. miRNA-200c inhibits invasion and metastasis of human non-small cell lung cancer by directly targeting ubiquitin specific peptidase 25. Mol Cancer. 2014; 13:166. doi: 10.1186/1476-4598-13-166.

83. Rodriguez a, Griffiths-Jones S, ashurst JL, Bradley A. Identification of mammalian microRNa host genes and transcription units. Genome Res. 2004; 14:1902-10.

84. Lee Y, Jeon K, Lee JT, Kim S, Kim VN. MicroRNA maturation: stepwise processing and subcellular localization. EMBO J. 2002; 21:4663-70.

85. Kim VN. MicroRNA precursors in motion: exportin-5 mediates their nuclear export. Trends Cell Biol. 2004; 14:156-59.

86. Kim VN, Han J, Siomi MC. Biogenesis of small RNAs in animals. Nat Rev Mol Cell Biol. 2009; 10:126-39.

87. Kim VN. MicroRNA biogenesis: coordinated cropping and dicing. Nat Rev Mol Cell Biol. 2005; 6:376-85.

88. Lee Y, Kim M, Han J, Yeom KH, Lee S, Baek SH, Kim VN. MicroRNA genes are transcribed by RNA polymerase II. EMBO J. 2004; 23:4051-60.

89. Han J, Lee Y, Yeom KH, Kim YK, Jin H, Kim VN. The Drosha-DGCR8 complex in primary microRNA processing. Genes Dev. 2004; 18:3016-27.

90. Hutvágner G, McLachlan J, Pasquinelli AE, Bálint E, Tuschl T, Zamore PD. A cellular function for the RNAinterference enzyme Dicer in the maturation of the let-7 small temporal RNA. Science. 2001; 293:834-38.

91. Ketting RF, Fischer SE, Bernstein E, Sijen T, Hannon GJ, Plasterk RH. Dicer functions in RNA interference and in synthesis of small RNA involved in developmental timing in C. elegans. Genes Dev. 2001; 15:2654-59.

92. Khvorova A, Reynolds A, Jayasena SD. Functional siRNAs and miRNAs exhibit strand bias. Cell. 2003; 115:209-216.

93. Schwarz DS, Hutvágner G, Du T, Xu Z, Aronin N, Zamore PD. Asymmetry in the assembly of the RNAi enzyme complex. Cell. 2003; 115:199-208.
94. Chakravarti D, Su X, Cho MS, Bui NH, Coarfa C, Venkatanarayan A, Benham AL, Flores González RE, Alana J, Xiao W, Leung ML, Vin H, Chan IL, et al. Induced multipotency in adult keratinocytes through down-regulation of $\Delta \mathrm{Np} 63$ or DGCR8. Proc Natl Acad Sci U S A. 2014; 111:E572-81. doi: 10.1073/ pnas.1319743111.

95. Mao A, Liu Y, Zhang H, Di C, Sun C. MicroRNA Expression and Biogenesis in Cellular Response to Ionizing Radiation. DNA Cell Biol. 2014; 33:667-79. doi: 10.1089/dna.2014.2401.

96. Ratovitski EA. Phospho- $\Delta$ Np63 $\alpha /$ microRNA network modulates epigenetic regulatory enzymes in squamous cell carcinomas. Cell Cycle. 2014; 13:749-61. doi: 10.4161/cc.27676.

97. Tran MN, Choi W, Wszolek MF, Navai N, Lee IL, Nitti G, Wen S, Flores ER, Siefker-Radtke A, Czerniak B, Dinney C, Barton M, McConkey DJ. The p63 protein isoform $\Delta \mathrm{Np} 63 \alpha$ inhibits epithelial-mesenchymal transition in human bladder cancer cells: role of MIR205. J Biol Chem. 2013; 288:3275-88. doi: 10.1074/jbc. M112.408104.

98. Knouf EC, Garg K, Arroyo JD, Correa Y, Sarkar D, Parkin RK, Wurz K, O'Briant KC, Godwin AK, Urban ND, Ruzzo WL, Gentleman R, Drescher CW, et al. An integrative genomic approach identifies p73 and p63 as activators of miR-200 microRNA family transcription. Nucleic Acids Res. 2012; 40:499-510. doi: 10.1093/nar/gkr731.

99. Antonini D, Russo MT, De Rosa L, Gorrese M, Del Vecchio L, Missero C. Transcriptional repression of miR-34 family contributes to p63-mediated cell cycle progression in epidermal cells. J Invest Dermatol. 2010; 130:1249-57. doi: 10.1038/jid.2009.438.

100. Rivetti di Val Cervo P, Lena AM, Nicoloso M, Rossi S, Mancini M, Zhou H, Saintigny G, Dellambra E, Odorisio T, Mahé C, Calin GA, Candi E, Melino G. p63microRNA feedback in keratinocyte senescence. Proc Natl Acad Sci U S A. 2012; 109:1133-8. doi: 10.1073/ pnas. 1112257109.

101. Li Y, Zhou Z, Chen C. WW domain-containing E3 ubiquitin protein ligase 1 targets p63 transcription factor for ubiquitin-mediated proteasomal degradation and regulates apoptosis. Cell Death Differ. 2008; 15:1941-51. doi: 10.1038/cdd.2008.134.

102. Candi E, Amelio I, Agostini M, Melino G. MicroRNAs and p63 in epithelial stemness. Cell Death Differ. 2014; doi: 10.1038/cdd.2014.113.

103. Muller PA, Trinidad AG, Caswell PT, Norman JC, Vousden KH. Mutant p53 regulates Dicer through p63-dependent and -independent mechanisms to promote an invasive phenotype. J Biol Chem. 2014; 289:122-32. doi: 10.1074/jbc.M113.502138.

104. Huang Y, Chuang A, Hao H, Talbot C, Sen T, Trink B, Sidransky D, Ratovitski E. Phospho- $\Delta \mathrm{Np} 63 \alpha$ is a key 
regulator of the cisplatin-induced microRNAome in cancer cells. Cell Death Differ. 2011; 18:1220-30. doi: 10.1038/ cdd.2010.188.

105. Boominathan $\mathrm{L}$. The tumor suppressors $\mathrm{p} 3$, p63, and $\mathrm{p} 73$ are regulators of microRNA processing complex. PLoS One. 2010; 5:e1061. doi: 10.1371/journal.pone.0010615.

106. Yokota I, Sasaki Y, Kashima L, Idogawa M, Tokino T. Identification and characterization of early growth response 2, a zinc-finger transcription factor, as a p53regulated proapoptotic gene. Int J Oncol. 2010; 37:1407-16.

107. Lagrange B, Martin RZ, Droin N, Aucagne R, Paggetti J, Largeot A, Itzykson R, Solary E, Delva L, Bastie JN. A role for miR-142-3p in colony-stimulating factor 1 -induced monocyte differentiation into macrophages. Biochim Biophys Acta. 2013; 1833:1936-46. doi: 10.1016/j.bbamcr.2013.04.007.

108. sse I, Barbollat-Boutrand L, Molina M, BerthierVergnes O, Joly-Tonetti N, Martin MT, Caron de Fromentel C, Kanitakis J, Lamartine J. Functional interplay between p63 and p53 controls RUNX1 function in the transition from proliferation to differentiation in human keratinocytes. Cell Death Dis. 2012; 3:e318. doi: 10.1038/cddis.2012.62.

109. Schmeier S, MacPherson CR, Essack M, Kaur M, Schaefer U, Suzuki H, Hayashizaki Y, Bajic VB. Deciphering the transcriptional circuitry of microRNA genes expressed during human monocytic differentiation. BMC Genomics. 2009; 10:595. doi: 10.1186/1471-2164-10-595.

110. Wang BD, Kline CL, Pastor DM, Olson TL, Frank B, Luu T, Sharma AK, Robertson G, Weirauch MT, Patierno SR, Stuart JM, Irby RB, Lee NH. Prostate apoptosis response protein 4 sensitizes human colon cancer cells to chemotherapeutic 5-FU through mediation of an NFkB and microRNA network. Mol Cancer. 2010; 9:98. doi: 10.1186/1476-4598-9-98.

111. Sen T, Sen N, Huang Y, Sinha D, Luo ZG, Ratovitski EA, Sidransky D. Tumor protein p63/nuclear factor $\kappa \mathrm{B}$ feedback loop in regulation of cell death. J Biol Chem. 2011; 286:43204-13. doi: 10.1074/jbc.M111.257105.

112. Ørom UA, Lim MK, Savage JE, Jin L, Saleh AD, Lisanti MP, Simone NL. MicroRNA-203 regulates caveolin-1 in breast tissue during caloric restriction. Cell Cycle. 2012; 11:1291-5. doi: 10.4161/cc.19704.

113. Wei T, Orfanidis K, Xu N, Janson P, Ståhle M, Pivarcsi A, Sonkoly E. The expression of microRNA-203 during human skin morphogenesis. Exp Dermatol. 2010; 19:8546. doi: 10.1111/j.1600-0625.2010.01118.x.

114. Melar-New M, Laimins LA. Human papillomaviruses modulate expression of microRNA 203 upon epithelial differentiation to control levels of $\mathrm{p} 63$ proteins. J Virol. 2010; 84:5212-21. doi: 10.1128/JVI.00078-10.

115. Jackson SJ, Zhang Z, Feng D, Flagg M, O'Loughlin E, Wang D, Stokes N, Fuchs E, Yi R. Rapid and widespread suppression of self-renewal by microRNA-203 during epidermal differentiation. Development. 2013; 140:188291. doi: 10.1242/dev.089649.

116. Yuan Y, Zeng ZY, Liu XH, Gong DJ, Tao J, Cheng HZ, Huang SD. MicroRNA-203 inhibits cell proliferation by repressing $\triangle \mathrm{Np} 63$ expression in human esophageal squamous cell carcinoma. BMC Cancer. 2011; 11:57. doi: 10.1186/1471-2407-11-57.

117. Yi R, Poy MN, Stoffel M, Fuchs E. A skin microRNA promotes differentiation by repressing 'stemness'. Nature. 2008; 452:225-9. doi: 10.1038/nature06642.

118. Lena AM, Shalom-Feuerstein R, Rivetti di Val Cervo P, Aberdam D, Knight RA, Melino G, Candi E. miR-203 represses 'stemness' by repressing DeltaNp63. Cell Death Differ. 2008; 15:1187-95. doi: 10.1038/cdd.2008.69.

119. Diao Y, Guo X, Jiang L, Wang G, Zhang C, Wan J, Jin Y, Wu Z. miR-203, a tumor suppressor frequently downregulated by promoter hypermethylation in rhabdomyosarcoma. J Biol Chem. 2014; 289:529-39. doi: 10.1074/ jbc.M113.494716.

120. Cao M, Deng X, Su S, Zhang F, Xiao X, Hu Q, Fu Y, Yang BB, Wu Y, Sheng W, Zeng Y. Protamine sulfatenanodiamond hybrid nanoparticles as a vector for MiR203 restoration in esophageal carcinoma cells. Nanoscale. 2013; 5:12120-5. doi: 10.1039/c3nr04056a.

121. Papagiannakopoulos $\mathrm{T}$, Shapiro A, Kosik KS. MicroRNA-21 targets a network of key tumor-suppressive pathways in glioblastoma cells. Cancer Res. 2008; 68:8164-72. doi: 10.1158/0008-5472.CAN-08-1305.

122. Wang T, Zhang L, Shi C, Sun H, Wang J, Li R, Zou Z, Ran X, Su Y. TGF- $\beta$-induced miR-21 negatively regulates the antiproliferative activity but has no effect on EMT of TGF- $\beta$ in HaCaT cells. Int J Biochem Cell Biol. 2012; 44:366-76. doi: 10.1016/j.biocel.2011.11.012.

123. Manni I, Artuso S, Careccia S, Rizzo MG, Baserga R, Piaggio G, Sacchi A. The microRNA miR-92 increases proliferation of myeloid cells and by targeting p63 modulates the abundance of its isoforms. FASEB, J. 2009; 23:3957-66. doi: 10.1096/fj.09-131847.

124. Quintavalle C, Donnarumma E, Iaboni M, Roscigno G, Garofalo M, Romano G, Fiore D, De Marinis P, Croce CM, Condorelli G. Effect of miR-21 and miR-30b/c on TRAIL-induced apoptosis in glioma cells. Oncogene. 2013; 32:4001-8. doi: 10.1038/onc.2012.410.

125. Scheel AH, Beyer U, Agami R, Dobbelstein M. Immunofluorescence-based screening identifies germ cell associated microRNA 302 as an antagonist to p63 expression. Cell Cycle. 2009; 8:1426-32.

126. Huang Y, Ratovitski EA. Phospho- $\Delta$ Np63 $\alpha /$ Rpn13-dependent regulation of LKB1 degradation modulates autophagy in cancer cells. Aging (Albany NY). 2010; 2:959-68.

127. Huang Y, Chuang AY, Romano RA, Liégeois NJ, Sinha S, Trink B, Ratovitski E, Sidransky D. PhosphoDeltaNp63alpha/NF-Y protein complex transcriptionally regulates DDIT3 expression in squamous cell carcinoma cells upon cisplatin exposure. Cell Cycle. 2010; 9:328-38. 
128. Ratovitski EA. Phospho- $\triangle \mathrm{Np} 63 \alpha$ regulates AQP3, ALOX12B, CASP14 and CLDN1 expression through transcription and microRNA modulation. FEBS Lett. 2013; 587:3581-6. doi: 10.1016/j.febslet.2013.09.023.

129. Ratovitski EA. Phospho- $\Delta \mathrm{Np} 63 \alpha$-dependent microRNAs modulate chemoresistance of squamous cell carcinoma cells to cisplatin: at the crossroads of cell life and death. FEBS Lett. 2013; 587:2536-41. doi: 10.1016/j. febslet.2013.06.020.

130. Huang Y, Kesselman D, Kizub D, Guerrero-Preston R, Ratovitski EA. Phospho- $\Delta$ Np63 $\alpha /$ microRNA feedback regulation in squamous carcinoma cells upon cisplatin exposure. Cell Cycle. 2013; 12:684-97. doi: 10.4161/cc.23598.

131. Lin CW, Li XR, Zhang Y, Hu G, Guo YH, Zhou JY, Du J, Lv L, Gao K, Zhang Y, Deng H. TAp63 suppress metastasis via miR-133b in colon cancer cells. Br J Cancer. 2014; 110:2310-20. doi: 10.1038/bjc.2014.118.

132. Melino G. p63 is a suppressor of tumorigenesis and metastasis interacting with mutant p53. Cell Death Differ. 2011; 18:1487-99. doi: 10.1038/cdd.2011.81.

133. Lau CP, Ng PK, Li MS, Tsui SK, Huang L, Kumta SM. p63 regulates cell proliferation and cell cycle progressionassociated genes in stromal cells of giant cell tumor of the bone. Int J Oncol. 2013; 42:437-43. doi: 10.3892/ ijo.2012.1727.
134. Jeon YJ, Jo MG, Yoo HM, Hong SH, Park JM, Ka SH, Oh $\mathrm{KH}$, Seol JH, Jung YK, Chung CH. Chemosensitivity is controlled by $\mathrm{p} 63$ modification with ubiquitin-like protein ISG15. J Clin Invest. 2012; 122:2622-36. doi: 10.1172/ JCI61762.

135. Wu G, Nomoto S, Hoque MO, Dracheva T, Osada M, Lee CC, Dong SM, Guo Z, Benoit N, Cohen Y, Rechthand P, Califano J, Moon CS, Ratovitski E, Jen J, Sidransky D, Trink B. DeltaNpalpha and TApalpha regulate transcription of genes with distinct biological functions in cancer and development. Cancer Res. 2003; 63:2351-7.

136. Osada M, Park HL, Nagakawa Y, Yamashita K, Fomenkov A, Kim MS, Wu G, Nomoto S, Trink B, Sidransky D. Differential recognition of response elements determines target gene specificity for p53 and p63. Mol Cell Biol. 2005; 25:6077-89.

137. Kim K, Madak-Erdogan Z, Ventrella R, Katzenellenbogen BS. A MicroRNA196a2* and TP63 circuit regulated by estrogen receptor- $\alpha$ and ERK2 that controls breast cancer proliferation and invasiveness properties. Horm Cancer. 2013; 4:78-91. doi: 10.1007/ s12672-012-0129-3.

138. Ory B, Ellisen LW. A microRNA-dependent circuit controlling p63/p73 homeostasis: p53 family cross-talk meets therapeutic opportunity. Oncotarget. 2011;2:259-64. 